\author{
ARTIFICIAL SATELLITES, Vol. 54, No. 3 - 2019 \\ DOI: 10.2478/arsa-2019-0007
}

\title{
USE OF THE SENTINEL-2A MULTISPECTRAL IMAGE FOR LITHO-STRUCTURAL AND ALTERATION MAPPING IN AL GLO'A MAP SHEET (1/50,000) (BOU AZZER-EL GRAARA INLIER, CENTRAL ANTI-ATLAS, MOROCCO)
}

\author{
Abdessamad EL ATILLAH*, Zine El Abidine EL MORJANI, Mustapha SOUHASSOU \\ Ibn Zohr University, Polydisciplinary Faculty of Taroudant, Egerne, Taroudant 83000, \\ Morocco \\ e-mail: elatillah@gmail.com (A. EL ATILLAH); z.elmorjani@uiz.ac.ma (Z.E.A. EL \\ MORJANI); m.souhassou@uiz.ac.ma (M. SOUHASSOU). \\ *Corresponding author
}

\begin{abstract}
The discovery of natural resources remains the main mission of Earth observation satellites, especially in geographical areas that have a very difficult accessibility as those of the Bou Azzer-El Graara inlier (Central Anti-Atlas, Morocco). This work investigates the use of different satellite data, such as Sentinel-2A's multispectral imagery, in order to direct the prospection program in an efficient manner, saving both time and cost. The image processing methods of Landsat 7, 8, and "Advanced Spaceborne Thermal Emission and Reflection Radiometer (ASTER)" (30 m/15 m) were used to create methods for Sentinel-2A images $(10 \mathrm{~m})$. The red, green, blue (RGB) image 12.8.2, 11/12.11/2.11/8, principal component (PC) 1,2,3(11.12.2), and other new images were the result of principal component analysis (PCA), and classification by the Iterative Self-Organizing Data Analysis Technique (ISODATA) and K-Means allowed realization of a lithological cartography as well as maps of lineaments through directional filters and the ratio of 11/12 for hydrothermal alteration zone mapping. The assembly of lithological, structural, and hydrothermal alteration data gave an idea of the mineralogy of the study area. Validity of the results was tested by comparison with the field data and the geological maps of the studied site $(62 \%$ for the hydrothermal alteration zone, $81 \%$ for the lithological map, and $74 \%$ for the structural map).
\end{abstract}

Keywords: remote sensing, multispectral image, Sentinel-2A, mineral prospecting, Bou Azzer-El Graara inlier (Morocco).

\section{INTRODUCTION}

In the field of geology, Landsat and Advanced Spaceborne Thermal Emission and Reflection Radiometer (ASTER) remain the most widely used Earth observation satellites. This work is part of the use of geomatics to direct prospectors to areas that may contain concentrations of ores. It will provide mining operators and exploration juniors with a decision-making tool that has the advantage of being economical, fast, and, above all, applicable in remote and inaccessible areas. The objective of this work is to evaluate the potential of Sentinel-2A multispectral imaging (MSI) for mineral resource mapping.

In Morocco, the new mining code, Law 33-13, has provided opportunities for exploration and research of large area of mineral resources through the introduction of the exploration license with a maximum perimeter of $2,400 \mathrm{~km}^{2}$ and the merger of research permits. Through 
the state of knowledge of the various aspects of the use of Landsat 7, 8, and ASTER geological multispectral satellite images, several treatment methods have been studied that are summarized in Table 1.

Table 1. (part one) Multispectral image processing methods for mineral prospecting

\begin{tabular}{|c|c|c|c|c|c|c|}
\hline Image & Satellite & Resolution & $\begin{array}{l}\text { Associated } \\
\text { processing }\end{array}$ & Study zone & $\begin{array}{l}\text { Author(s) and } \\
\text { year }\end{array}$ & Result \\
\hline 543 & \multirow{6}{*}{ L 7} & \multirow{6}{*}{30} & \multirow{6}{*}{$\mathrm{F}^{\circ}, \mathrm{F}^{\circ} 5^{\circ}, \mathrm{F} 90^{\circ}$} & \multirow{6}{*}{$\begin{array}{l}\text { Djelfa, } \\
\text { Algeria }\end{array}$} & \multirow{6}{*}{$\begin{array}{l}\text { Amri et al., } \\
2017\end{array}$} & \multirow{6}{*}{$\begin{array}{l}\text { Lithology and } \\
\text { lineaments map }\end{array}$} \\
\hline 751 & & & & & & \\
\hline $3 / 47 / 52 / 3$ & & & & & & \\
\hline $2 / 13 / 27 / 5$ & & & & & & \\
\hline PC1, 2, 3(571) & & & & & & \\
\hline $\mathrm{PC} 1,2,3(573)$ & & & & & & \\
\hline $\begin{array}{l}1457 \\
1345 \\
\end{array}$ & L 7 & 30 & PCA & $\begin{array}{l}\text { Gördes } \\
\text { region } \\
\text { (Turkey) }\end{array}$ & $\begin{array}{l}\text { Vural et al., } \\
2016\end{array}$ & $\begin{array}{l}\text { Exploring } \\
\text { Gördes zeolite } \\
\text { sites }\end{array}$ \\
\hline $6 / 57 / 64 / 7$ & L 8 & 30 & \multirow{11}{*}{ SVM } & \multirow{11}{*}{$\begin{array}{l}\text { Draa Bas, } \\
\text { Maroc }\end{array}$} & \multirow{11}{*}{$\begin{array}{l}\text { Adiri et al., } \\
2016\end{array}$} & \multirow[b]{2}{*}{$\begin{array}{l}\text { Lithological } \\
\text { discrimination }\end{array}$} \\
\hline $\begin{array}{l}(6+8) / 49 / 4 \\
5 / 3\end{array}$ & ASTER & 15 & & & & \\
\hline $6 / 5$ & L 8 & 30 & & & & \multirow{2}{*}{ Clay } \\
\hline $5 / 3$ & ASTER & 15 & & & & \\
\hline $5 / 4$ & L 8 & 30 & & & & \multirow{2}{*}{ Alluvium } \\
\hline $3 / 2$ & ASTER & 15 & & & & \\
\hline $4 / 7$ & L 8 & 30 & & & & \multirow{2}{*}{ Schist } \\
\hline $3 / 6$ & ASTER & 15 & & & & \\
\hline $7 / 6$ & L 8 & 30 & & & & \multirow{2}{*}{$\begin{array}{l}\text { Granite and } \\
\text { biotite }\end{array}$} \\
\hline$(6+8) / 4$ & ASTER & 30 & & & & \\
\hline $9 / 4$ & ASTER & 30 & & & & Rhyolite \\
\hline $\begin{array}{l}\mathrm{B} 1, \mathrm{~B} 4, \mathrm{~B} 6, \\
\text { and B7 } \\
\mathrm{B} 1, \mathrm{~B} 3, \mathrm{~B} 4, \\
\text { and B8 }\end{array}$ & ASTER & 30 & PCA & $\begin{array}{l}\text { Arequipa } \\
\text { province of } \\
\text { South Peru }\end{array}$ & $\begin{array}{l}\text { Wang et al., } \\
2015\end{array}$ & $\begin{array}{l}\text { Mineral } \\
\text { alteration }\end{array}$ \\
\hline $\begin{array}{l}\text { Band } 5 \text { of the } \\
\text { level-1B and } \\
\text { level-2 } \\
\text { (AST2B05S) } \\
\text { SWIR }\end{array}$ & ASTER & 30 & SAM & $\begin{array}{l}\text { Sar } \\
\text { Cheshmeh in } \\
\text { Iran }\end{array}$ & $\begin{array}{l}\text { Shahriari et al., } \\
2015\end{array}$ & $\begin{array}{l}\text { Hydrothermal } \\
\text { alteration } \\
\text { mapping }\end{array}$ \\
\hline 573 & L 7 & \multirow[t]{4}{*}{30} & \multirow{4}{*}{ PCA } & \multirow{4}{*}{$\begin{array}{l}\text { Central } \\
\text { region of } \\
\text { Kenya }\end{array}$} & \multirow{4}{*}{$\begin{array}{l}\text { Mwaniki et al., } \\
2015\end{array}$} & \multirow{4}{*}{$\begin{array}{l}\text { Litho-structural } \\
\text { map }\end{array}$} \\
\hline 674 & L 8 & & & & & \\
\hline $3 / 25 / 17 / 3$ & L 7 & & & & & \\
\hline $4 / 36 / 27 / 4$ & L 8 & & & & & \\
\hline $4 / 26 / 75 / 10$ & L 8 & 30 & --- & Iran & $\begin{array}{l}\text { Pour and } \\
\text { Hashim, } 2014\end{array}$ & Alteration zone \\
\hline
\end{tabular}


Table 1. (part two) Multispectral image processing methods for mineral prospecting

\begin{tabular}{|c|c|c|c|c|c|c|}
\hline 731 & & & & & & \\
\hline 742 & & & & & & Lithological \\
\hline $5 / 74 / 51 / 3$ & & & & & & discrimination \\
\hline $5 / 33 / 17 / 5$ & & & & & & \\
\hline 432 & & & & & & $\begin{array}{l}\text { Lithological } \\
\text { discrimination, } \\
\text { the vegetation } \\
\text { appears in red }\end{array}$ \\
\hline 754 & & & & & & $\begin{array}{l}\text { Lithological } \\
\text { discrimination, } \\
\text { the vegetation } \\
\text { appears in blue }\end{array}$ \\
\hline $3 / 1$ & L 7 & 30 & $\begin{array}{l}\text { Normal and } \\
\text { selective PCA }\end{array}$ & $\begin{array}{l}\text { Hang, } \\
\text { Algeria }\end{array}$ & $\begin{array}{l}\text { Achek and } \\
\text { Aidouni, } 2014\end{array}$ & $\begin{array}{l}\text { Good } \\
\text { discrimination } \\
\text { for rocks } \\
\text { subjected to } \\
\text { hydrothermal } \\
\text { alteration and } \\
\text { for iron oxides }\end{array}$ \\
\hline $1 / 2,2 / 1$ & & & & & & $\begin{array}{l}\text { Good } \\
\text { discrimination } \\
\text { for rocks rich in } \\
\text { iron oxides }\end{array}$ \\
\hline $5 / 7$ & & & & & & $\begin{array}{l}\text { Good } \\
\text { discrimination } \\
\text { for rocks rich in } \\
\text { Al-OH }\end{array}$ \\
\hline $7 / 5$ & & & & & & $\begin{array}{l}\text { Good } \\
\text { discrimination } \\
\text { of clays }\end{array}$ \\
\hline $5 / 4$ & & & & & & $\begin{array}{l}\text { Good } \\
\text { discrimination } \\
\text { of iron oxides }\end{array}$ \\
\hline $5 / 7$ & $\mathrm{TM}$ & 30 & & & $\begin{array}{l}\text { Al Hakim and } \\
\text { Sulistijo, } 2013\end{array}$ & $\begin{array}{l}\text { Zone } \\
\text { d'altération }\end{array}$ \\
\hline $\begin{array}{l}\text { Band ratio } \\
\text { composites } \\
([6 / 3-1 / 3-9 / 5] \\
\text { and }[8 / 6-8 / 7- \\
4 / 7][\text { RGB] }\end{array}$ & ASTER & 30 & FOPCA & $\begin{array}{l}\text { Wadi Kid, } \\
\text { southeastern } \\
\text { Sinai } \\
\text { peninsula, } \\
\text { Egypt }\end{array}$ & $\begin{array}{l}\text { Gad and Raef, } \\
2012\end{array}$ & $\begin{array}{l}\text { Lithological } \\
\text { mapping }\end{array}$ \\
\hline 752 & L 7 & $30 / 15$ & $\begin{array}{l}\text { Fusion with B8 } \\
(15 \mathrm{~m}) \text { and } \mathrm{F} \text {. } \\
\text { D. }\end{array}$ & Ivory Coast & $\begin{array}{l}\text { Ouattara et al., } \\
2012\end{array}$ & $\begin{array}{l}\text { Litho-structural } \\
\text { map }\end{array}$ \\
\hline $30 \mathrm{~m}$ strips & L 7 & $30 \mathrm{~m}$ & OIF & & $\begin{array}{l}\text { Imessaoudene, } \\
2012\end{array}$ & Lithology \\
\hline $\begin{array}{l}\text { Ratio } 4 / 9 \text { and } \\
\text { RGB } \\
\text { composite } 148\end{array}$ & ASTER & 30 & FOPCA & Ankara Bala & $\begin{array}{l}\text { Öztan and } \\
\text { Süzen, } 2011\end{array}$ & $\begin{array}{l}\text { Mapping } \\
\text { evaporate } \\
\text { minerals } \\
\text { (gypsum) }\end{array}$ \\
\hline $\begin{array}{l}\text { Four RGB } \\
\text { combinations } \\
(3,5,6, \text { and } 8)\end{array}$ & ASTER & 30 & SAM & $\begin{array}{l}\text { Mainland } \\
\text { Gujarat, } \\
\text { India }\end{array}$ & $\begin{array}{l}\text { Nair and } \\
\text { Mathew, } 2012\end{array}$ & $\begin{array}{l}\text { Lithological } \\
\text { map }\end{array}$ \\
\hline
\end{tabular}


Table 1. (part three) Multispectral image processing methods for mineral prospecting

\begin{tabular}{|c|c|c|c|c|c|c|}
\hline 321 & \multirow{4}{*}{ L 7} & \multirow{4}{*}{30} & \multirow{4}{*}{$\begin{array}{l}\text { Directional filte } \\
\text { r } 0^{\circ}, 45^{\circ}, 90^{\circ}, \\
\text { and } 135^{\circ} \\
\text { Matrix } 3 * 3 \text { and } \\
7 * 7\end{array}$} & \multirow{4}{*}{$\begin{array}{l}\text { Central } \\
\text { Hoggar, } \\
\text { Algeria }\end{array}$} & \multirow{4}{*}{$\begin{array}{l}\text { Amri et al., } \\
2009\end{array}$} & \multirow{4}{*}{$\begin{array}{l}\text { Lithological } \\
\text { discrimination } \\
\text { lineaments map }\end{array}$} \\
\hline 742 & & & & & & \\
\hline $5 / 75 / 15 / 4$ & & & & & & \\
\hline $5 / 34 / 23 / 1$ & & & & & & \\
\hline 567 & L 7 & 30 & --- & $\begin{array}{l}\text { Northeast of } \\
\text { Hajjah, } \\
\text { Yemen }\end{array}$ & $\begin{array}{l}\text { Qaid and } \\
\text { Basavarajappa, } \\
2008 \\
\end{array}$ & Lithology \\
\hline 468 & ASTER & 30 & ---- & & Mike, 2005 & \\
\hline 753 & L 7 & 30 & & Sudan & Shaddad, 2005 & $\begin{array}{l}\text { Delineation of } \\
\text { dry soil and } \\
\text { distinct rock } \\
\text { surfaces }\end{array}$ \\
\hline 7/visible & \multirow{5}{*}{$\begin{array}{l}\text { Landsat } \\
\text { TM } \\
\text { MSS }\end{array}$} & \multirow{5}{*}{30} & \multirow{5}{*}{----} & \multirow{5}{*}{ Tunisia } & \multirow{5}{*}{$\begin{array}{l}\text { Escadafal and } \\
\text { Peuget, } 1987\end{array}$} & $\begin{array}{l}\text { Mineralization } \\
\text { (gypsum) }\end{array}$ \\
\hline $5 / 46 / 57 / 6$ & & & & & & Alteration \\
\hline $3 / 23 / 15 / 7$ & & & & & & \\
\hline $7 / 3$ & & & & & & Lithology \\
\hline $3 / 5$ & & & & & & Snow and ice \\
\hline
\end{tabular}

Key: ASTER, Advanced Spaceborne Thermal Emission and Reflection Radiometer; FOPCA, featureoriented principal component analysis; PC, principal component; PCA, principal component analysis; RGB, red, green, blue; SAM, spectral angle mapper; TM, Thematic Mapper; MSS, Multispectral Scanner System; OIF, Optimum Index Factor ; SVM, support vector machine; SWIR, Short-Wave Infrared.

Our study area, red square in Figure 1, the area covered by Al Glo'a leaf, belongs to the domain of the central Moroccan Anti-Atlas that consists of a mountainous chain with polyphase deformation that runs along the northwestern edge of the West African Craton. Located about $100 \mathrm{~km}$ southwest of Ouarzazate, the Al Glo'a leaf forms part of a perimeter at the southern end of Bou Azzer-El Graara eastern inlier, along the major accident of the AntiAtlas in its central part. This area constitutes a reference in the Moroccan geological literature for the understanding of Precambrian events of the Anti-Atlas. This interest is accentuated by the great metallogenic richness of this inlier (cobalt, copper, gold, barite, etc.) (Soulaimani et al., 2013b).

The area covered by the Al Glo'a (Figure 1) sheet is positioned on the eastern end of the Bou Azzer-El Graara inlier. This corresponds to two contiguous depressions (Bou Azzer and El Graara) extended WNW-ESE over a length of approximately $67 \mathrm{~km}$ and a maximum width of $15 \mathrm{~km}$. Morphologically, by looking from a low position, the inlier is surrounded by Paleozoic sedimentary cover cliffs. The altitude of the inlier lands is mainly around $1,300 \mathrm{~m}$, while the cuestas of the cover areas frequently reach 1,400-1,500 $\mathrm{m}$ and exceed 1,600 $\mathrm{m}$ on several occasions (Soulaimani et al., 2013b). 


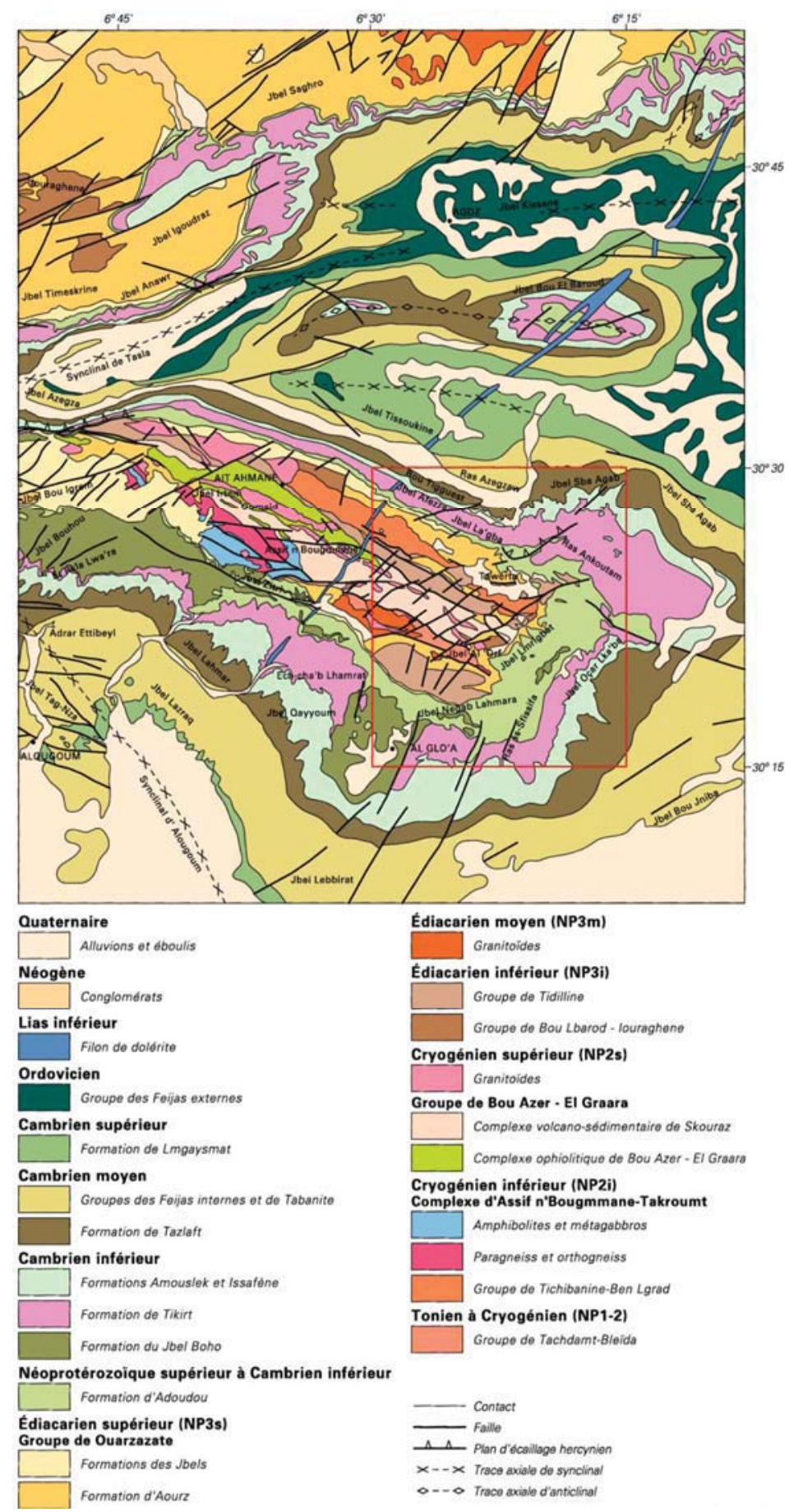

Fig. 1. Geological setting of the study area (red square) (Soulaimani et al., 2013b)

\section{MATERIAL}

The Sentinel-2A MSI instrument captures images of 13 spectral bands ranging from visible to mid-infrared over a width of $290 \mathrm{~km}$ (Table 2):

- The four spectral bands (blue [490 nm], green [560 nm], red [665 nm], and near infrared [842 $\mathrm{nm}]$ ) having a resolution of $10 \mathrm{~m}$;

- Three spectral bands (443, 945, and $1,375 \mathrm{~nm})$ are provided with a resolution of 60 $\mathrm{m}$; and

- Six bands are provided with $20 \mathrm{~m}$ (bands $\mathrm{N}^{\circ}: 5$ [705 nm], 6 [740 nm], 7 [783 nm], $8 \mathrm{~A}[865 \mathrm{~nm}], 11[1,610 \mathrm{~nm}]$, and 12 [2,190 nm]). 
Table 2. Sentinel-2A MSI bands (GDAL)

\begin{tabular}{|l|l|l|l|l|}
\hline $\begin{array}{c}\text { Band } \\
\text { name }\end{array}$ & $\begin{array}{c}\text { Resolution } \\
(\mathrm{m})\end{array}$ & \multicolumn{1}{c|}{$\begin{array}{c}\text { Central wavelength } \\
(\mathrm{nm})\end{array}$} & $\begin{array}{c}\text { Bandwidth } \\
(\mathrm{nm})\end{array}$ & \multicolumn{1}{c|}{ Purpose } \\
\hline B01 & 60 & 443 & 20 & Aerosol detection \\
\hline B02 & 10 & 490 & 65 & Blue \\
\hline B03 & 10 & 560 & 35 & Green \\
\hline B04 & 10 & 665 & 30 & Red \\
\hline B05 & 20 & 705 & 15 & Vegetation classification \\
\hline B06 & 20 & 740 & 15 & Vegetation classification \\
\hline B07 & 20 & 783 & 20 & Vegetation classification \\
\hline B08 & 10 & 842 & 115 & Near infrared \\
\hline B08A & 20 & 865 & 20 & Vegetation classification \\
\hline B09 & 60 & 945 & 20 & Water vapor \\
\hline B10 & 60 & 1,375 & 30 & Cirrus \\
\hline B11 & 20 & 1,610 & 90 & $\begin{array}{l}\text { Snow/ice/cloud } \\
\text { discrimination }\end{array}$ \\
\hline B12 & 20 & 2,190 & 180 & $\begin{array}{l}\text { Snow/ice/cloud } \\
\text { discrimination }\end{array}$ \\
\hline
\end{tabular}

Key: MSI, multispectral imaging.

MSI database, a multispectral instrument, has made it possible to directly download images of the Sentinel already corrected for atmospheric effects via the website https://scihub.copernicus.eu/dhus/\#/home. We have chosen an image, Figure $2 \mathrm{c}$ and d, with the product type S2MSI2Ap (Sentinel-2A; 2015) and the processing level 2Ap, picked up on 09 April 2017 at 10 h 56 min $51 \mathrm{~s}$ in Bou Azzer-El Graara area. It is characterized by 97\% bare soil, $0.08 \%$ cloud cover, $0 \%$ snow ice, $1.01 \%$ vegetation, and $0.000013 \%$ water.

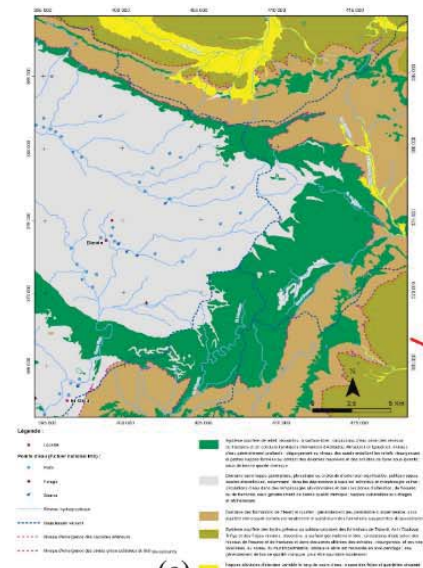

(e)

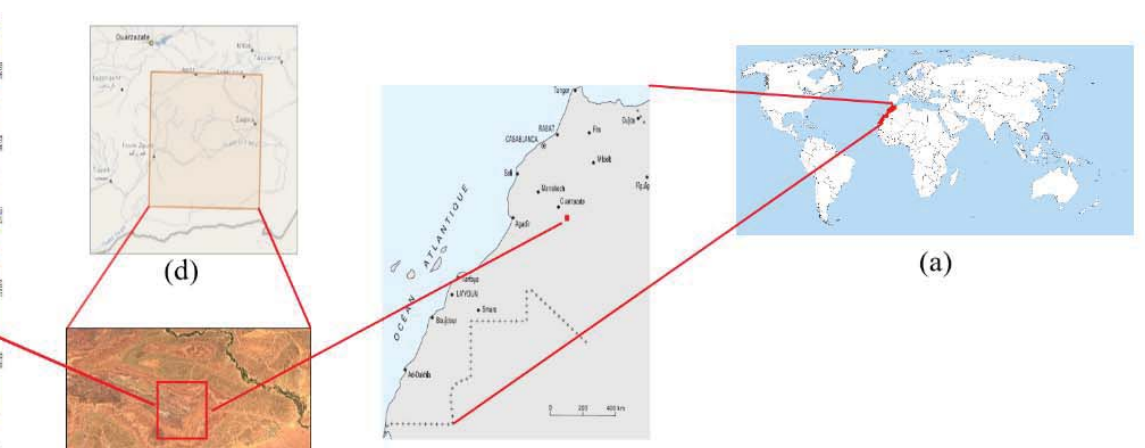

(b)

Fig. 2. Study area location: (a) Morocco's location in the world; (b) location of the sheet of $\mathrm{Al}$ Glo'a in Morocco; (c) location of the sheet of Al Glo'a in the initial Sentinel-2A image; (d) location of the initial Sentinel-2A image; and (e) the sheet of Al Glo'a (hydrogeological map)

In this work, we have studied only a part of the image (Figure 2), extracted by the technique of Imagine Erdas Area of Interest (AOI), relating to the Al Glo'a map sheet at scale 1/50,000 (Figure 3 and red squares in Figures 1 and 2). This study area is limited by the boundaries shown in Table 3 . 
Table 3. The coordinates of the bounds of Al Glo'a sheet $(1 / 50,000)$

\begin{tabular}{|c|c|}
\hline \multirow{2}{*}{ Geodetic system } & World Geodetic System 1984 (WGS 84) \\
\cline { 2 - 2 } & DMS (Degrees, Minutes, Seconds) \\
\hline Borne $\mathrm{n}^{\circ} 1$ & $\begin{array}{c}\text { Latitude: } 30^{\circ} 30^{\prime} \mathrm{N} \\
\text { Longitude: } 6^{\circ} 15^{\prime} \mathrm{W}\end{array}$ \\
\hline Borne $\mathrm{n}^{\circ} 2$ & $\begin{array}{c}\text { Latitude: } 30^{\circ} 30^{\prime} \mathrm{N} \\
\text { Longitude: } 6^{\circ} 30^{\prime} \mathrm{W}\end{array}$ \\
\hline Borne $\mathrm{n}^{\circ} 3$ & $\begin{array}{c}\text { Latitude: } 30^{\circ} 15^{\prime} \mathrm{N} \\
\text { Longitude: } 6^{\circ} 30^{\prime} \mathrm{W}\end{array}$ \\
\hline Borne $\mathrm{n}^{\circ} 4$ & $\begin{array}{c}\text { Latitude: } 30^{\circ} 15^{\prime} \mathrm{N} \\
\text { Longitude: } 6^{\circ} 15^{\prime} \mathrm{W}\end{array}$ \\
\hline
\end{tabular}

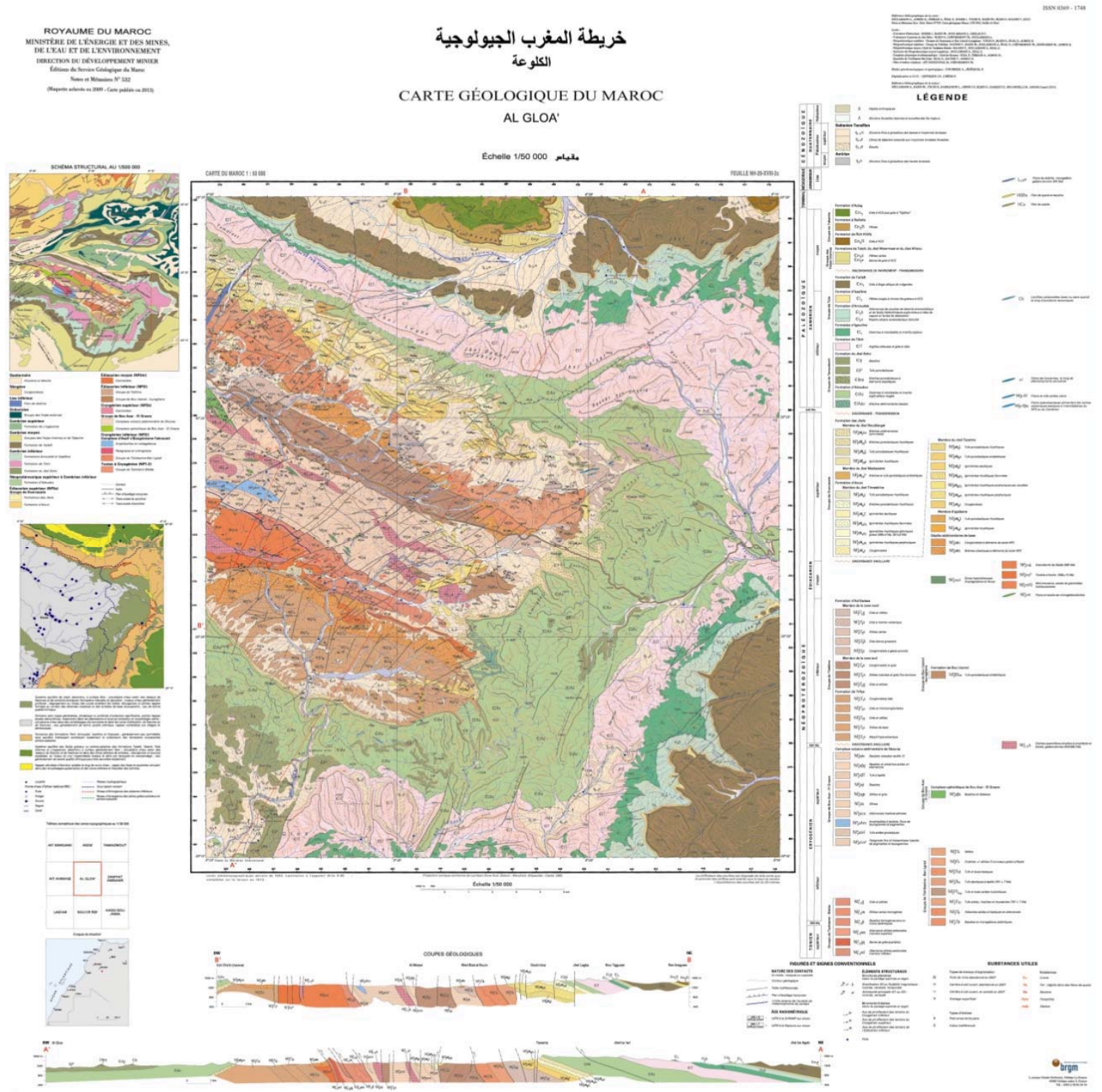

Fig. 3. Geological map of Al Glo'a of 1/50,000 (Soulaimani et al., 2013a) 
The outcrops of Neoproterozoic rocks in the central part of Al Glo'a sheet (Figure 3) are covered by upper Ediacaran volcano-sedimentary rocks (Ouarzazate group) and a lower Paleozoic sedimentary cover (Soulaimani et al., 2013b).

\section{METHOD}

The approach adopted in this article is the use of remote sensing space techniques that can be deployed downstream of conventional exploration programs. This requires significant technical and financial resources and, especially, accessibility that remains very difficult in the field. The processing methods mentioned above (Table 1) will be the subject of an analogy based on the correspondence between the bands of the different satellites and Sentinel-2. The goal is to move to a high resolution of $10 \mathrm{~m}$ instead of $30 \mathrm{~m}$ to provide information on the lithology and geological structures, which are valuable for mineral prospecting and exploration activities. Figure 4 shows a comparison among the Landsat 7, 8, ASTER, MODIS, and Sentinel bands.

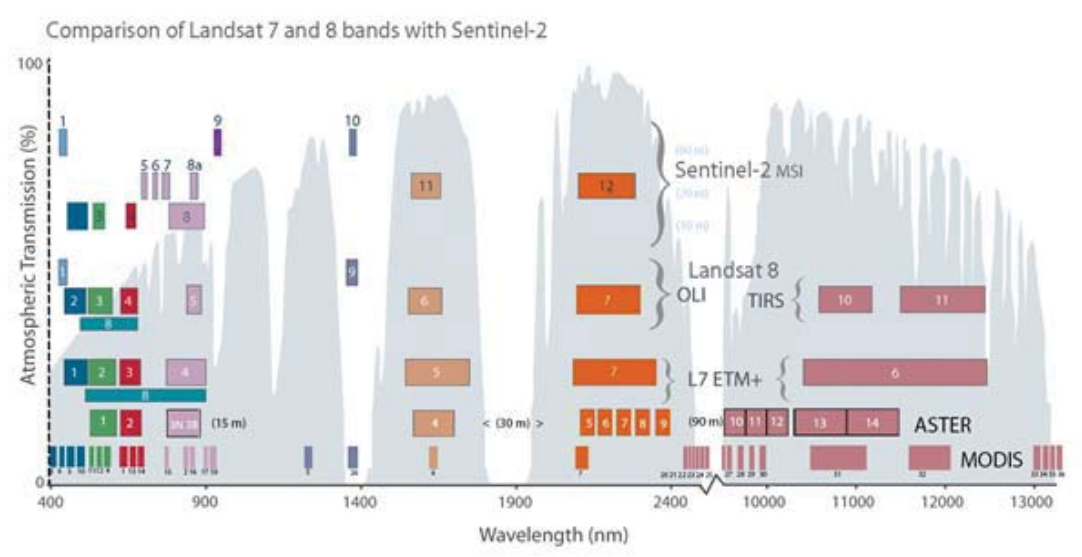

Fig. 4. Comparison of Landsat 7, 8, Sentinel-2, ASTER, and MODIS bands (USGS Landsat Program)

Through this comparison, one can make an analogy to create a method of treatment with Sentinel-2A. Table 4 presents several methods of treatment after deletion of those that do not correspond with the bands of the MSI (bands 8, 9, 10, 11, 12, 13, and 14 of ASTER; bands 10 and 11 of Landsat 8 and band 6 of Landsat 7). 
Table 4. MSI Sentinel-2A image processing methods

\begin{tabular}{|c|c|c|c|}
\hline Image & Satellite & Sentinel-2A image by analogy & Resolution (m) \\
\hline 543 & \multirow{6}{*}{ L 7} & 11.8 .4 & 10 \\
\hline 751 & & 12.11 .2 & 10 \\
\hline $3 / 47 / 52 / 3$ & & $4 / 8.12 / 11.3 / 4$ & 10 \\
\hline $2 / 13 / 27 / 5$ & & $3 / 2.4 / 3.12 / 11$ & 10 \\
\hline $\mathrm{PC} 1,2,3(571)$ & & $\mathrm{PC} 1,2,3(11.12 .2)$ & 10 \\
\hline PC1, 2, 3(573) & & $\mathrm{PC} 1,2,3(11.12 .4)$ & 10 \\
\hline $6 / 57 / 64 / 7$ & L 8 & $11 /(8$ or $8 \mathrm{~A}) .12 / 11.4 / 12$ & 10 or 20 \\
\hline $6 / 5$ & L 8 & \multirow{2}{*}{$11 /(8$ or $8 \mathrm{~A})$} & \multirow[t]{2}{*}{10 or 20} \\
\hline $5 / 4$ & L 7 & & \\
\hline $5 / 3$ & ASTER & $12 / 8$ & 10 \\
\hline $5 / 4$ & L 8 & \multirow{2}{*}{$(8$ or $8 \mathrm{~A}) / 4$} & \multirow[t]{2}{*}{10 or 20} \\
\hline $3 / 2$ & ASTER & & \\
\hline $4 / 7$ & L 8 & $4 / 12$ & 10 \\
\hline $3 / 6$ & ASTER & $8 / 12$ & 10 \\
\hline $7 / 6$ & L 8 & \multirow{4}{*}{$12 / 11$} & \multirow[t]{4}{*}{20} \\
\hline$(6+8) / 4$ & ASTER & & \\
\hline $5 / 7$ & $\mathrm{~L} 7$ & & \\
\hline $5 / 7$ & TM & & \\
\hline 573 & L 7 & \multirow{2}{*}{11.12 .4} & \multirow[t]{2}{*}{10} \\
\hline 674 & L 8 & & \\
\hline $3 / 25 / 17 / 3$ & L 7 & \multirow{2}{*}{$4 / 3.11 / 2.12 / 4$} & \multirow[t]{2}{*}{10} \\
\hline $4 / 36 / 27 / 4$ & L 8 & & \\
\hline 731 & \multirow{7}{*}{ L 7} & 12.4 .2 & 10 \\
\hline $5 / 74 / 51 / 3$ & & $11 / 12.8 / 11.2 / 4$ & 10 \\
\hline $5 / 33 / 17 / 5$ & & $11 / 4.4 / 2.12 / 11$ & 10 \\
\hline 432 & & 8.4 .3 & 10 \\
\hline 754 & & 12.11 .8 & 10 \\
\hline $3 / 1$ & & $4 / 2$ & 10 \\
\hline $1 / 2,2 / 1$ & & $2 / 3.3 / 2$ & 10 \\
\hline 752 & L 7 & 12.11 .3 & 10 \\
\hline 321 & \multirow{4}{*}{ L 7} & 432 & 10 \\
\hline 742 & & 12.8 .3 & 10 \\
\hline $5 / 75 / 15 / 4$ & & $11 / 12.11 / 2.11 / 8$ & 10 \\
\hline $5 / 34 / 23 / 1$ & & $11 / 4.8 / 3.4 / 2$ & 10 \\
\hline 7/visible & \multirow{4}{*}{ L 5} & $12 /$ visible $(2,3$, and 4$)$ & 10 \\
\hline $3 / 23 / 15 / 7$ & & $4 / 3.4 / 2.11 / 12$ & 10 \\
\hline $7 / 3$ & & $12 / 4$ & 10 \\
\hline $3 / 5$ & & $4 / 11$ & 10 \\
\hline
\end{tabular}

Key: ASTER, Advanced Spaceborne Thermal Emission and Reflection Radiometer; MSI, multispectral imaging; PC, principal component.

After visualizing the different ratios and normal red, green, blue images (RGBs) and the one that results from the principal component analysis (PCA), we chose the images that give 
good results. These are the subject of treatments through the PCA and unsupervised classification to define lithology, other algorithms for structural mapping, and ratio 11/12 for hydrothermal alteration zones. The method is summarized in Figure 5.

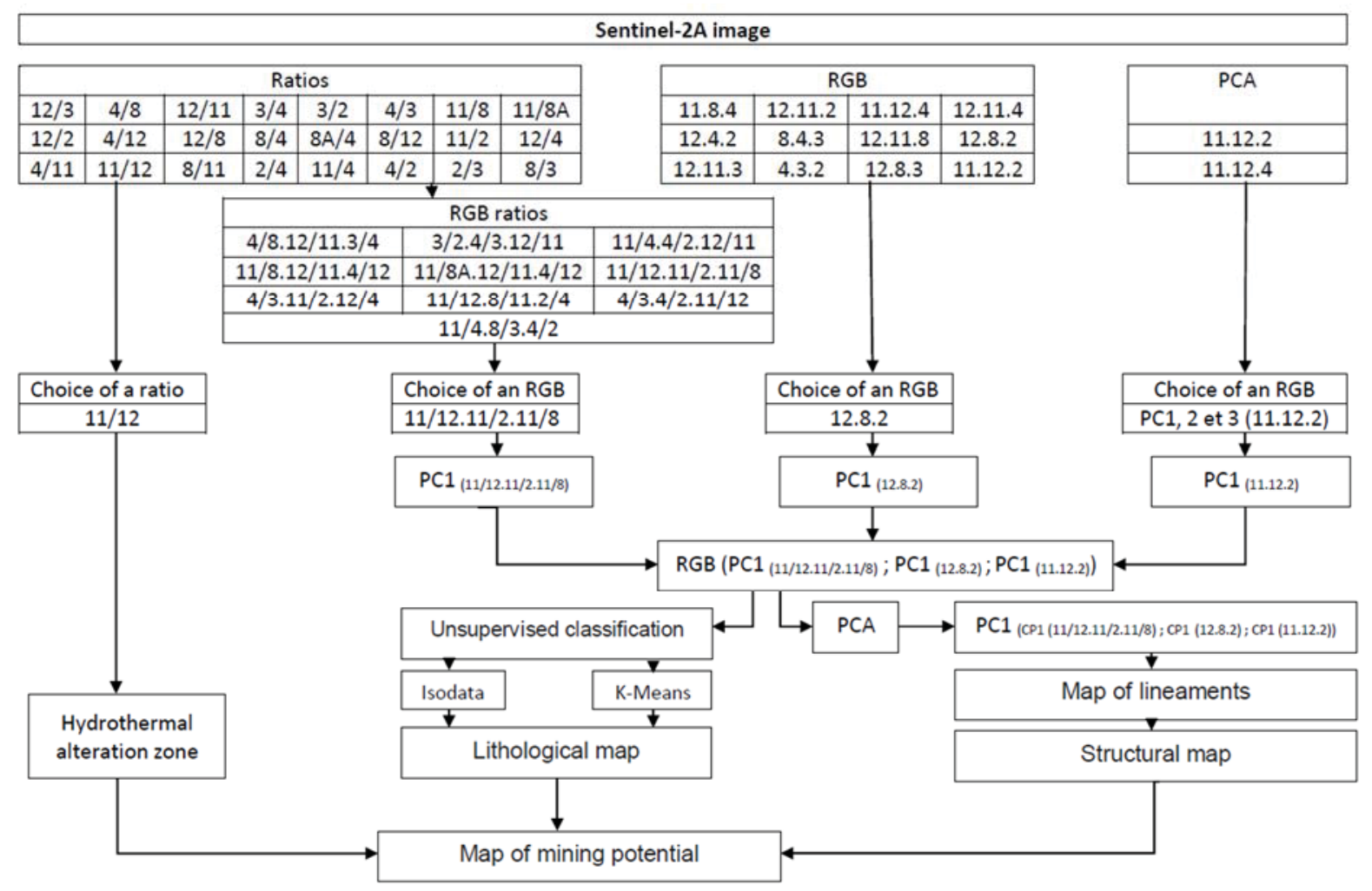

Fig. 5. Treatment method used

Key: PCA, principal component analysis; RGB, red, green, blue.

\section{RESULTS}

In this article, we have presented all the resulting images of the different treatments of the methods used. All these images listed in this part have the same scale $(1 / 50,000)$ and the same elements as the GLO'A map (Figure 3). They are oriented toward north with the same coordinates of the edges shown in Table 3. 


\subsection{Band reports}

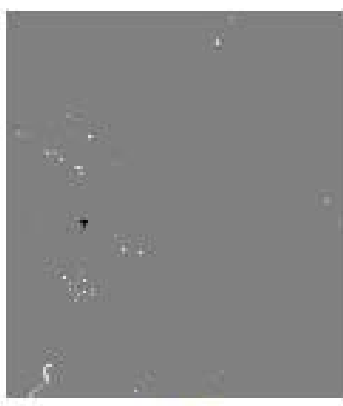

(a)

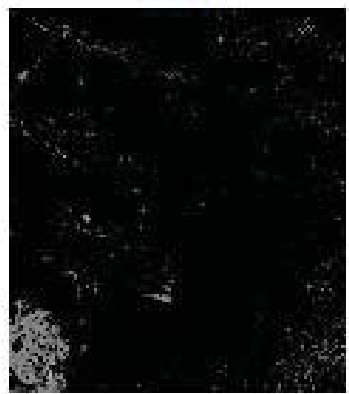

(d)

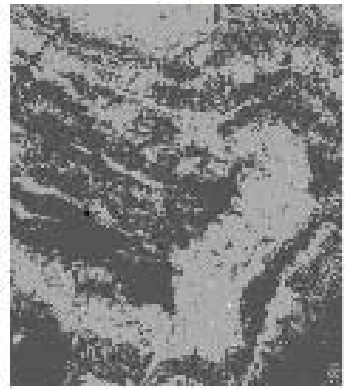

(g)

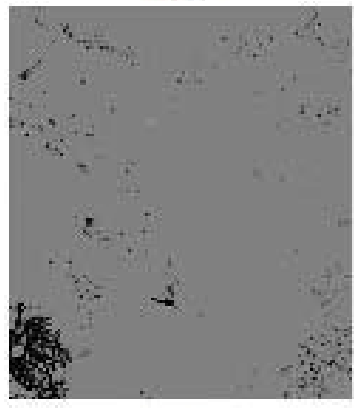

(j)

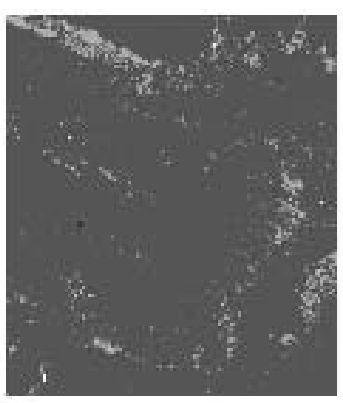

(b)

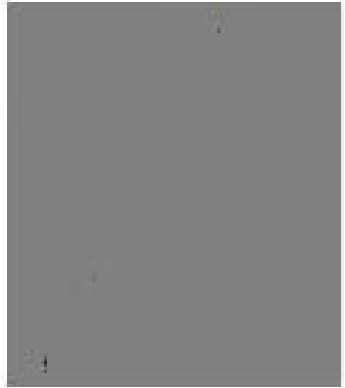

(e)

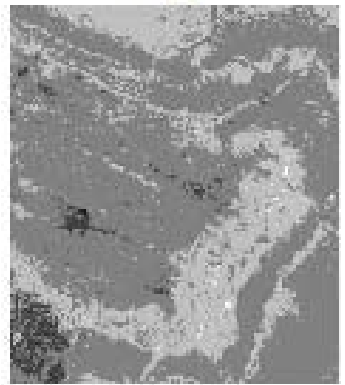

(h)

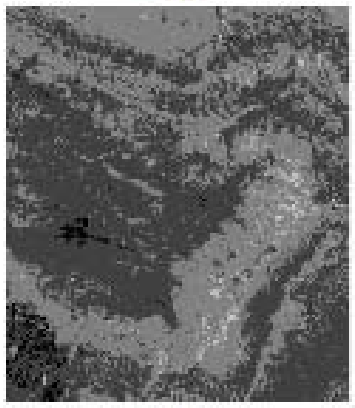

(k)

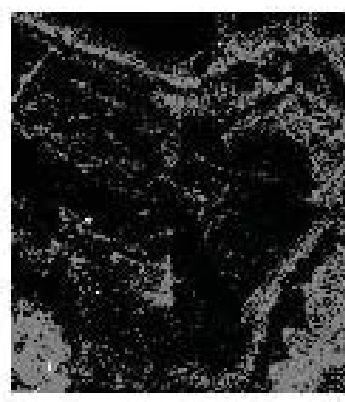

(c)

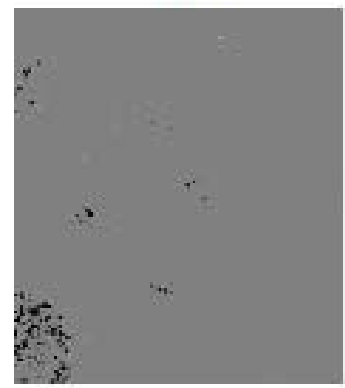

(f)

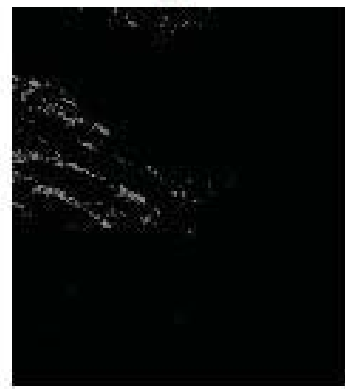

(i)

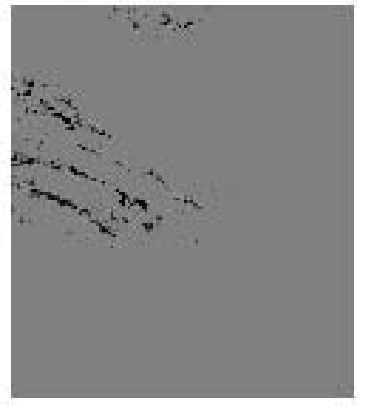

(l)

Fig. 6. Band reports (1/50,000): (a) $8 / 4$, (b) $8 / 3$, (c) $8 / 12$, (d) $8 / 11$, (d) $8 / 11$, (e) $4 / 3$, (f) $12 / 4$, (g) $12 / 3$, (h) $12 / 2$, (i) $12 / 11$, (j) $11 / 8$, (k) $11 / 2$, and (l) $11 / 12$ 


\subsection{Composites colored in RGB}

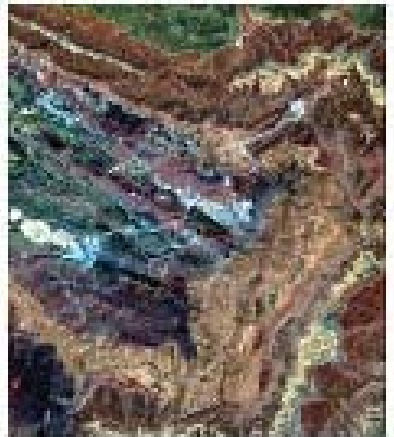

(a)

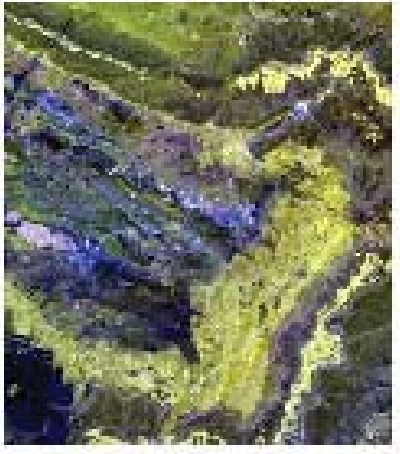

(d)

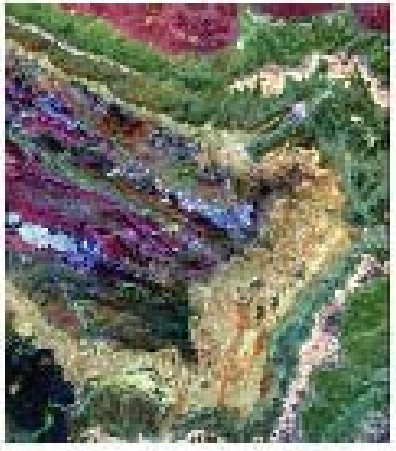

(g)

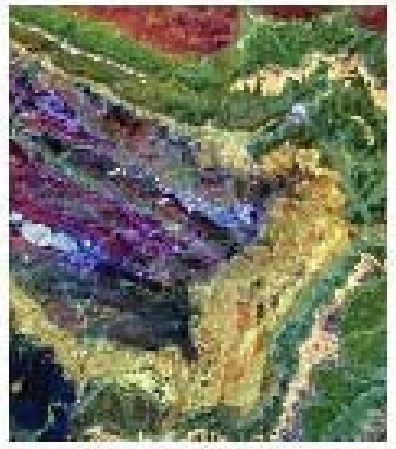

(j)

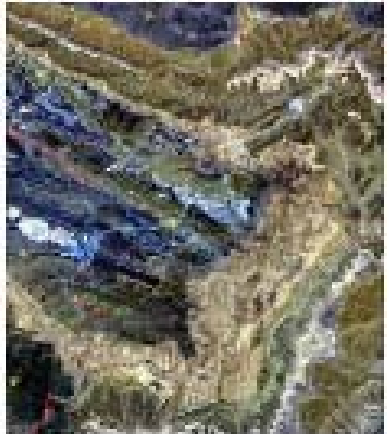

(b)

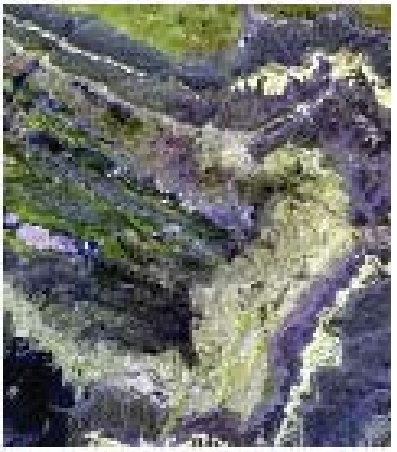

(e)

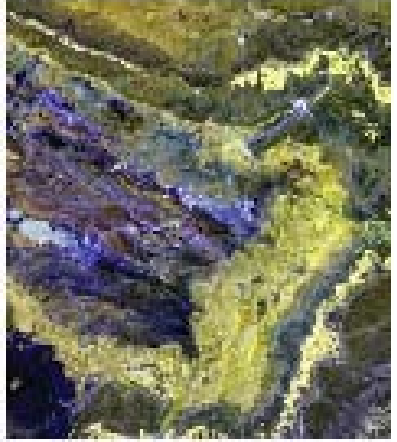

(h)

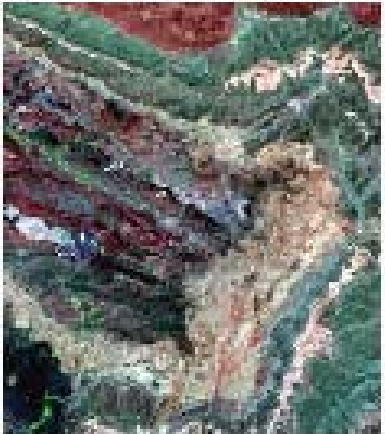

(c)

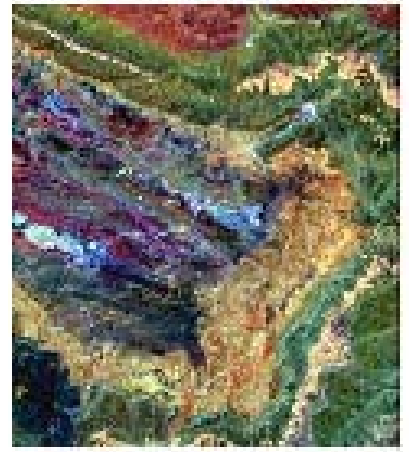

(f)

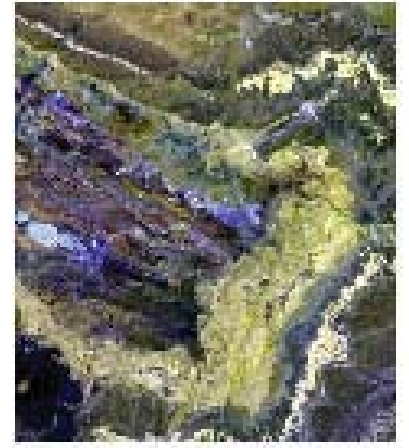

(i)

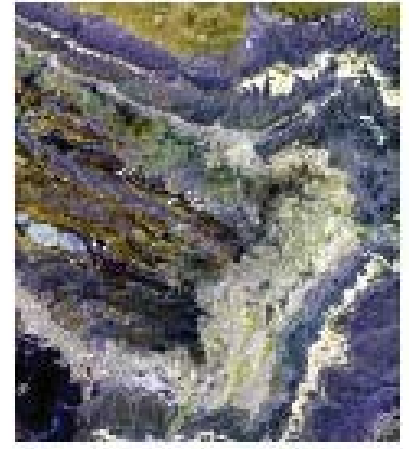

(k)

Fig. 7. Composites colored in RGB (1/50,000): (a) 432, (b) 843, (c) 11.8.4, (d) 11.12.2, (e) 11.12.4, (f) 12.4.2, (g) 12.8.3, (h) 12.11.2, (i) 12.11.3, (j) 12.8.2, (k) 12.11.8

Key: RGB, red, green, blue. 


\subsection{Composites colored in RGB ratios}

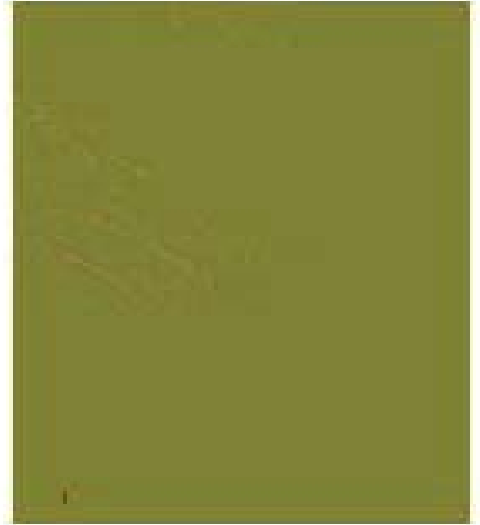

(a)

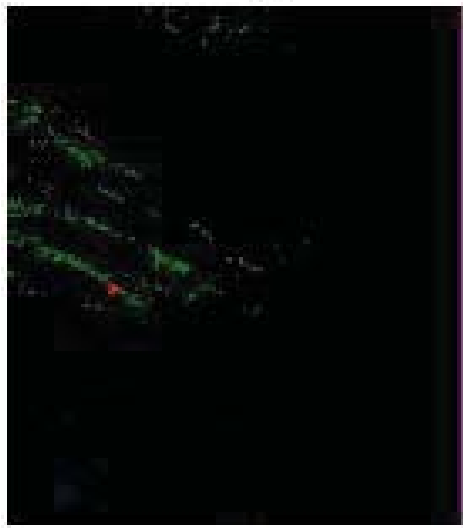

(d)

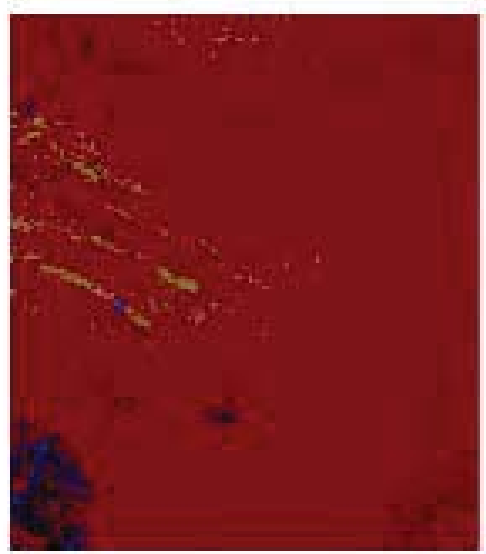

(g)

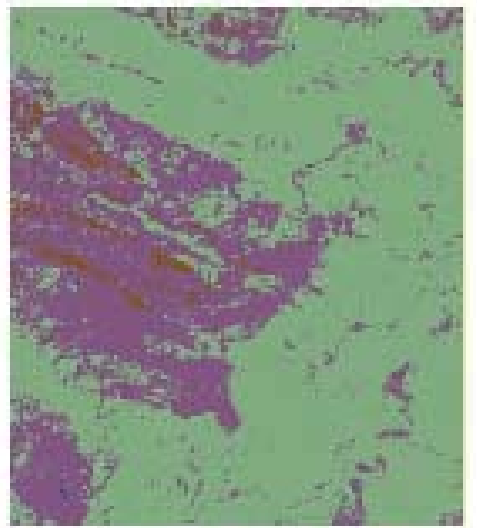

(b)

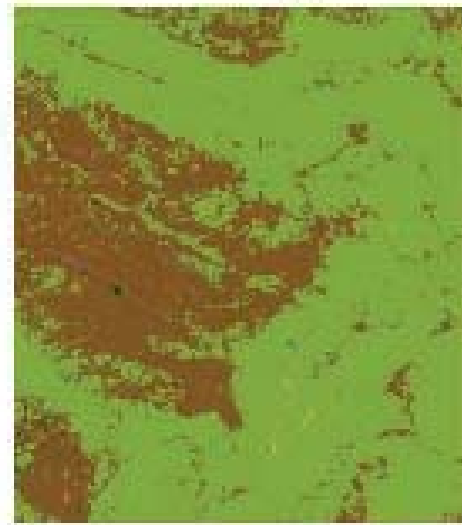

(e)

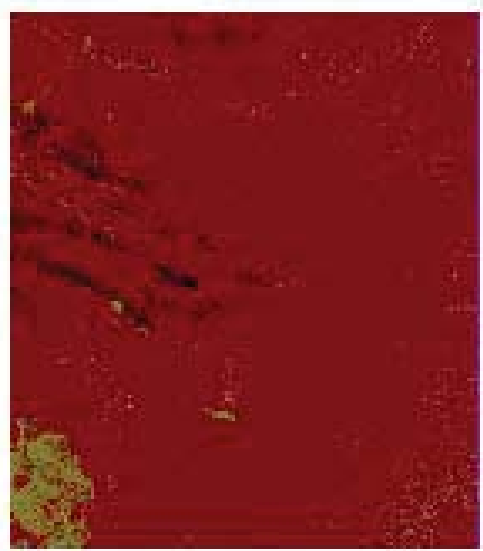

(h)

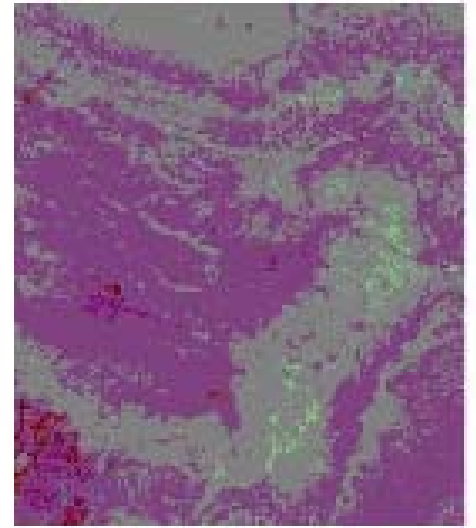

(c)

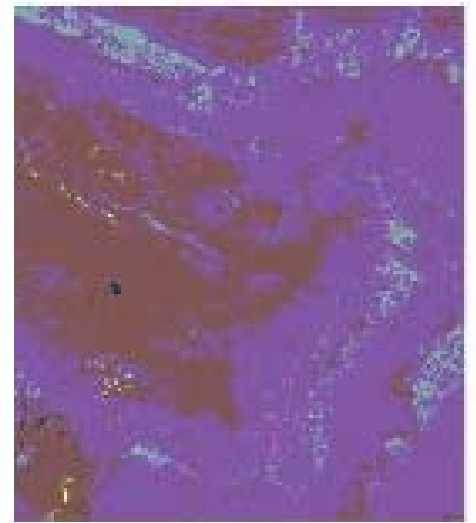

(f)

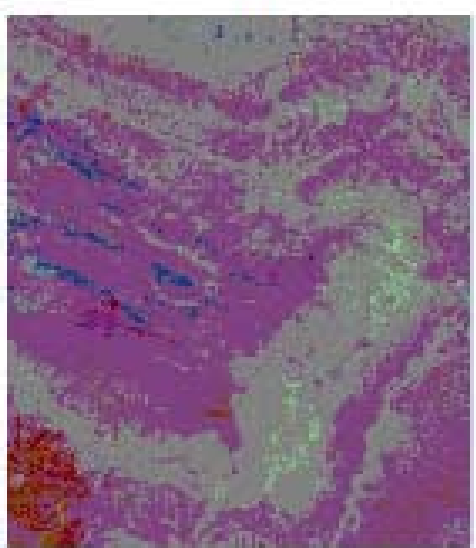

(i)

Figure 8. Composites colored in RGB ratios (1/50,000): (a) 3/2.4/3.12/11, (b) 4/3.4/2.11/12, (c) $4 / 3.11 / 2.12 / 4$, (d) $4 / 8.12 / 11.3 / 4$, (e) $11 / 4.4 / 2.12 / 11$, (f) $11 / 4.8 / 3.4 / 2$, (g) $11 / 8.12 / 11.4 / 12$, (h) $11 / 12.8 / 11.2 / 4$, (i) $11 / 12.11 / 2.11 / 8$

Key: RGB, red, green, blue. 


\subsection{Principal component analysis}

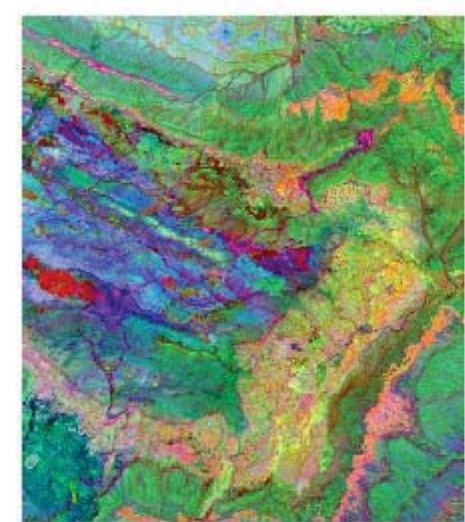

(a)

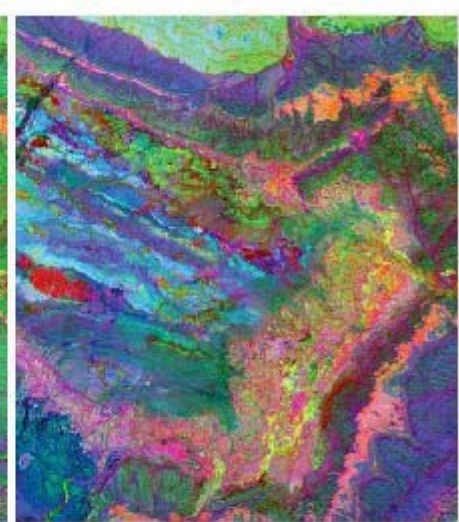

(b)

Fig. 9. PCA (1/50,000): (a) PCA RGB PC1,2,3 (11.12.2), (b) PCA RGB PC1,2,3 (11.12.4)

Key: PCA, principal component analysis; RGB, red, green, blue.

\subsection{The neo-channels}

Neo-channels are composites of the initial bands of a satellite image; they are the result of the arithmetic operations of the original bands.

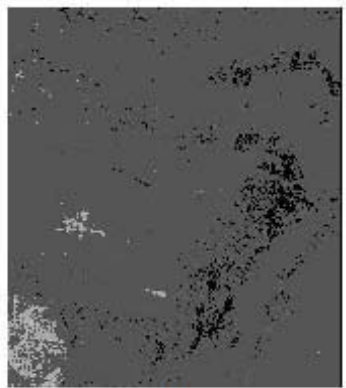

(a)

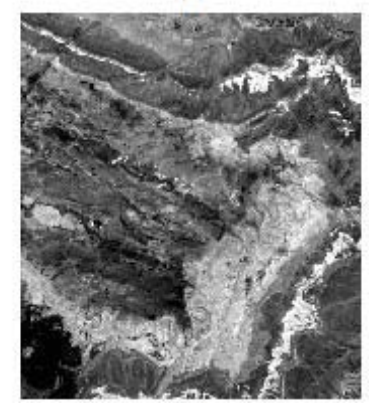

(c)

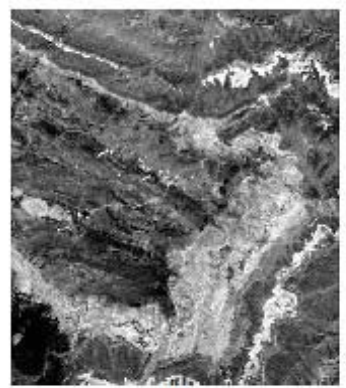

(b)

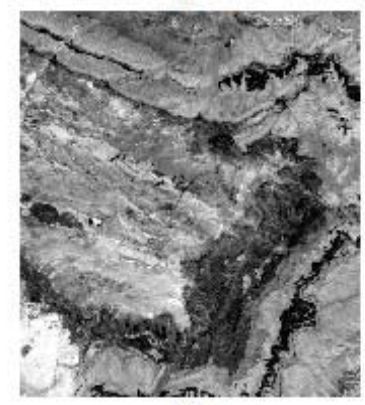

(d)

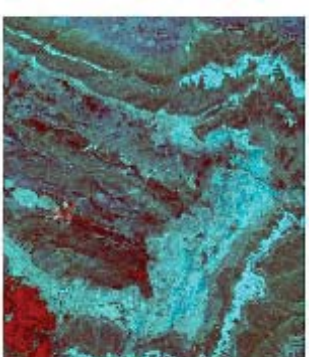

(e)

Fig. 10. The neo-channels (1/50,000): (a) $\mathrm{PC} 1_{(11 / 12.11 / 2.11 / 8)}$, (b) $\mathrm{PC} 1_{(12.8 .2)}$, (c) $\mathrm{PC} 1_{(11.12 .2)}$, (d) PC1 (CP1 (11/12.11/2.11/8); CP1 (12.8.2); CP1 (11.12.2)), (e) RGB (CP1 (11/12.11/2.11/8); CP1 (12.8.2); CP1 (11.12.2))

Key: PC, principal component; RGB, red, green, blue. 


\subsection{Unsupervised classification}

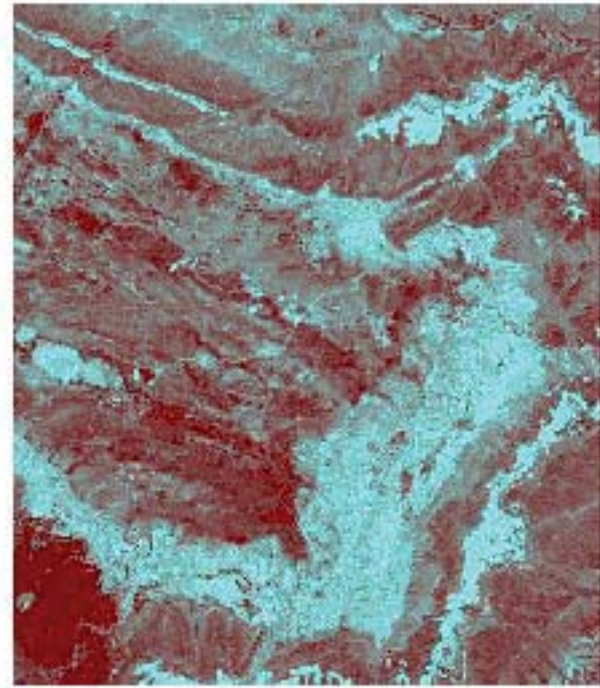

(a)

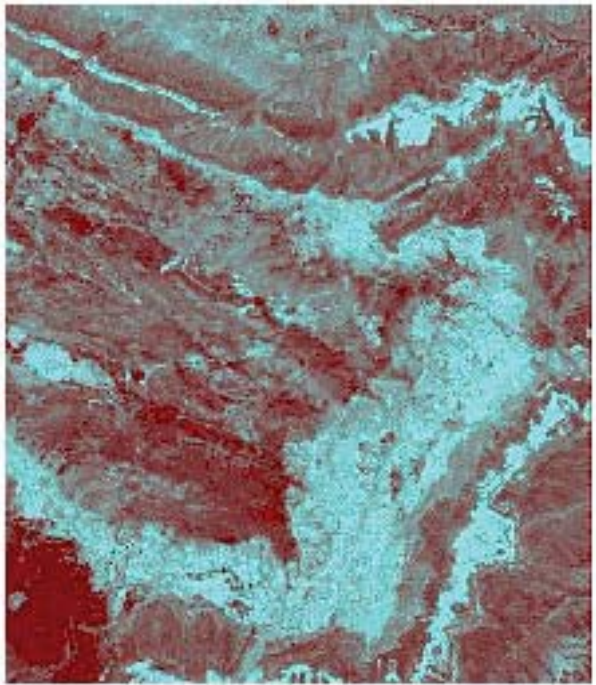

(b)

Fig. 11. Unsupervised classification (1/50,000): (a) algorithm: ISODATA (10 classes), (b) algorithm: K-Means (10 classes)

Key: ISODATA, Iterative Self-Organizing Data Analysis Technique.

\subsection{Linear chart}

Table 5 shows the different criteria for the choice of type of lineaments.

Table 5. Criteria of linear chart

\begin{tabular}{|l|c|c|c|c|c|}
\hline \multirow{2}{*}{ Criteria } & \multicolumn{5}{|c|}{ Case } \\
\cline { 2 - 6 } & 1 & 2 & 3 & 4 & 5 \\
\hline Filter radius (pixels) & 10 & 10 & 7 & 7 & 10 \\
\hline Edge gradient threshold & 100 & 100 & 100 & 100 & 100 \\
\hline Curve length threshold (pixels) & 30 & 100 & 50 & 20 & 20 \\
\hline Line fitting error threshold (pixels) & 3 & 3 & 3 & 3 & 3 \\
\hline Angular difference threshold (degrees) & 30 & 30 & 30 & 30 & 30 \\
\hline Linking distance threshold (pixels) & 20 & 20 & 5 & 5 & 20 \\
\hline
\end{tabular}




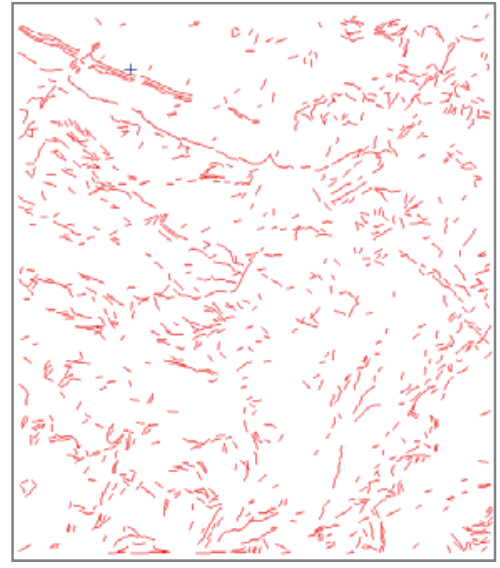

(a)

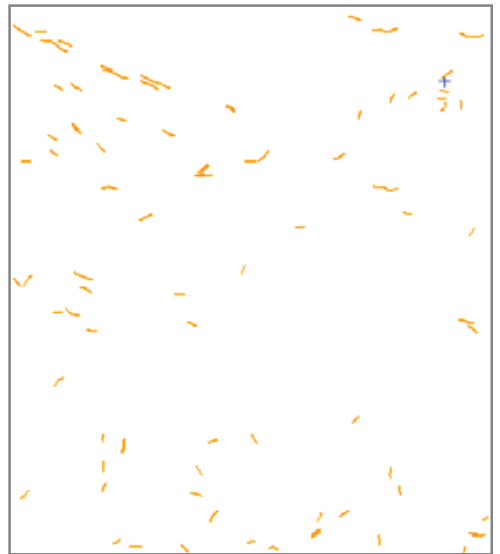

(c)

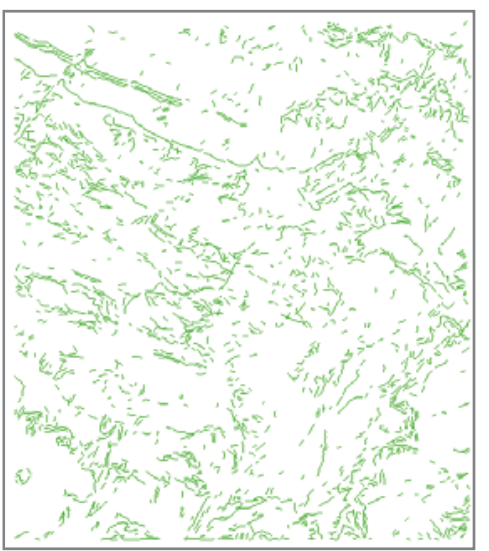

(e)

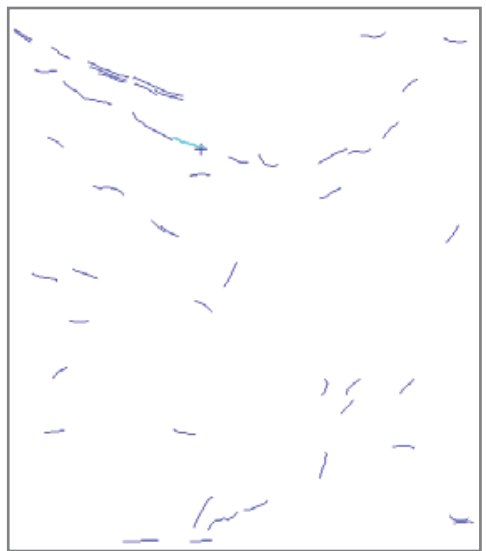

(b)

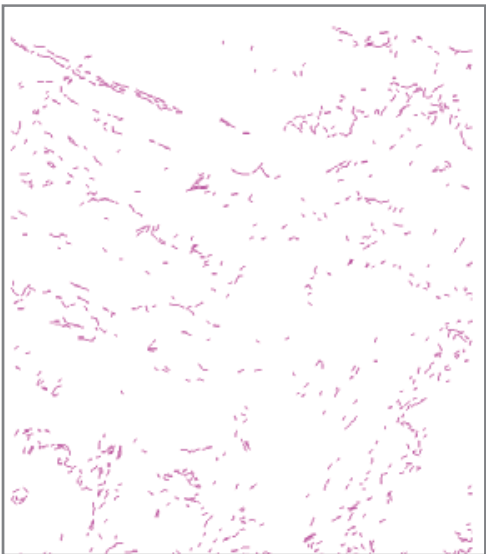

(d)

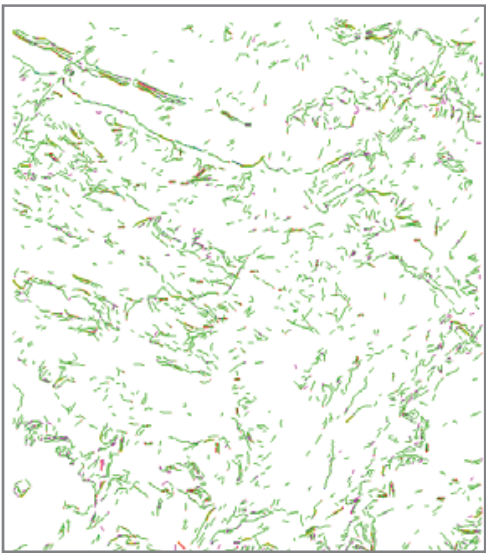

(f)

Fig. 12. Case images of linear chart $(1 / 50,000)$ : (a) linear chart of case 1; (b) linear chart of case 2; (c) linear chart of case 3; (d) linear chart of case 4; (e) linear chart of case 5; and (f) linear chart of the five cases

\section{DISCUSSION}

\subsection{Band reports (ratios)}

We can visualize precise geological formations from the ratios. Table 6 presents the usefulness of the important ratios. 
Table 6. The usefulness of Sentinel-2A image ratios

\begin{tabular}{|l|l|}
\hline Sentinel-2A ratio & \multicolumn{1}{|c|}{ Utility } \\
\hline $8 / 4$ and $8 \mathrm{~A} / 4$ & Vegetation in white \\
\hline $4 / 3$ & Vegetation in black \\
\hline $8 / 3$ & $\begin{array}{l}\text { Feces cones associated with medium-sized fluvial terraces, oblique } \\
\text { megadid sandstone beds, and adoudou gray formation; vegetation in } \\
\text { white }\end{array}$ \\
\hline $8 / 12$ & Sandstone oblique of megaripples, silty clay, and sandstone wrinkles \\
\hline $8 / 11$ & Pyroclastic tuffs \\
\hline $12 / 4$ & $\begin{array}{l}\text { Adoudou formation, microbialite dolomites, clayey interlites, basalts, } \\
\text { indurated siltstones, fine sandstones, and alluvial fans associated with } \\
\text { medium fluvial terraces }\end{array}$ \\
\hline $12 / 3$ & Adoudou formation and pyroclastic tuffs \\
\hline $12 / 11$ & $\begin{array}{l}\text { Gray aphyric rhyolitic ignimbrites, sandstone, pelites, marble-schist } \\
\text { alternations, pyroclastic rhyolitic breccias }\end{array}$ \\
\hline $11 / 8$ and 11/8A & $\begin{array}{l}\text { Alternation of stromatolitic dolomite layers, clay-silty heterolytic } \\
\text { facies with wave lines, micro-gabbro and pyroclastic tuffs }\end{array}$ \\
\hline $11 / 2$ & Adoudou formation, silty clay, and sandstone wrinkles \\
\hline
\end{tabular}

Hydrothermal alteration is linked to the underground circulation, which can attract the surface of hot water, loaded with dissolved minerals (Ar, Copper, Barite, etc.). This circulation of hydrothermal fluids often occurs in the veins in volcanic zone, near a magma chamber, or in plutonic zone. It dissolves the minerals present in the rocks crossed. Figure $6 \mathrm{i}$ and 1 shows the hydrothermal alteration zone (Figure 6i, white color and Figure 61, black color).

\subsection{Composites colored in RGB}

After a comparative study among the different composites $(11.8 .4,12.11 .2,11.12 .4,12.11 .4$, 12.4.2, 8.4.3, 12.11.8, 12.8.2, 12.11.3, 4.3.2, 12.8.3, 11.12.2), we chose the 12.8 .2 composite in RGB. The latter has a very good geological discrimination (Figure $7 \mathrm{j}$ ).

\subsection{Colored composites of RGB ratios}

Comparison among color composites with ratios in RGB (4/8.12/11.3/4, 3/2.4/3.12/11, 11/4.4/2.12/11, 11/8.12/11.4/12, 11/8A.12/11.4/12, 11/12.11/2.11/8, 4/3.11/2.12/4, $11 / 12.8 / 11.2 / 4,4 / 3.4 / 2.11 / 12$, and 11/4.8/3.4/2) shows that the composite 11/12.11/2.11/8 has surface lithological discrimination (Figure 8i). In this image, the geological formations appear in several colors: the adoudou in gray, sandstone oblique of megaripples, argillites silty and purple sandstone wrinkles, alluvial fans associated with medium fluviatile terraces in orange, pyroclastic tuffs in brown, and doleritic basalts and microgabbros in blue.

\subsection{Principal component analysis}

The PCA is part of the group of multidimensional descriptive methods called factorial methods. The PCA proposes, from a rectangular table of data containing the values of $p$ quantitative variables for $n$ units, geometric representations of these units. These variables make it possible to determine the main components (principal component [PC]) that represent the contribution of the original tapes involving the spectral response of relevant substances and the spectral information of minerals of particular interest. It is used to create new uncorrelated components by identifying the axes in the original data that account for the largest amount of variation. This method has always shown the effectiveness of the results 
related to geological discrimination and mineral exploration. Minerals and substances are represented as dark or bright pixels in PC images, respectively, according to the sign of the charge of the proper vector (Corumluoglu et al., 2015; Vural et al., 2017). The satisfactory results obtained by this technique guide us to use this technique at different stages of this process (Figure 9). The PCA has developed a high precision with respect to the existing geological map, as illustrated in Figure 13. This figure is the result of a comparison between these two well-georeferenced images.

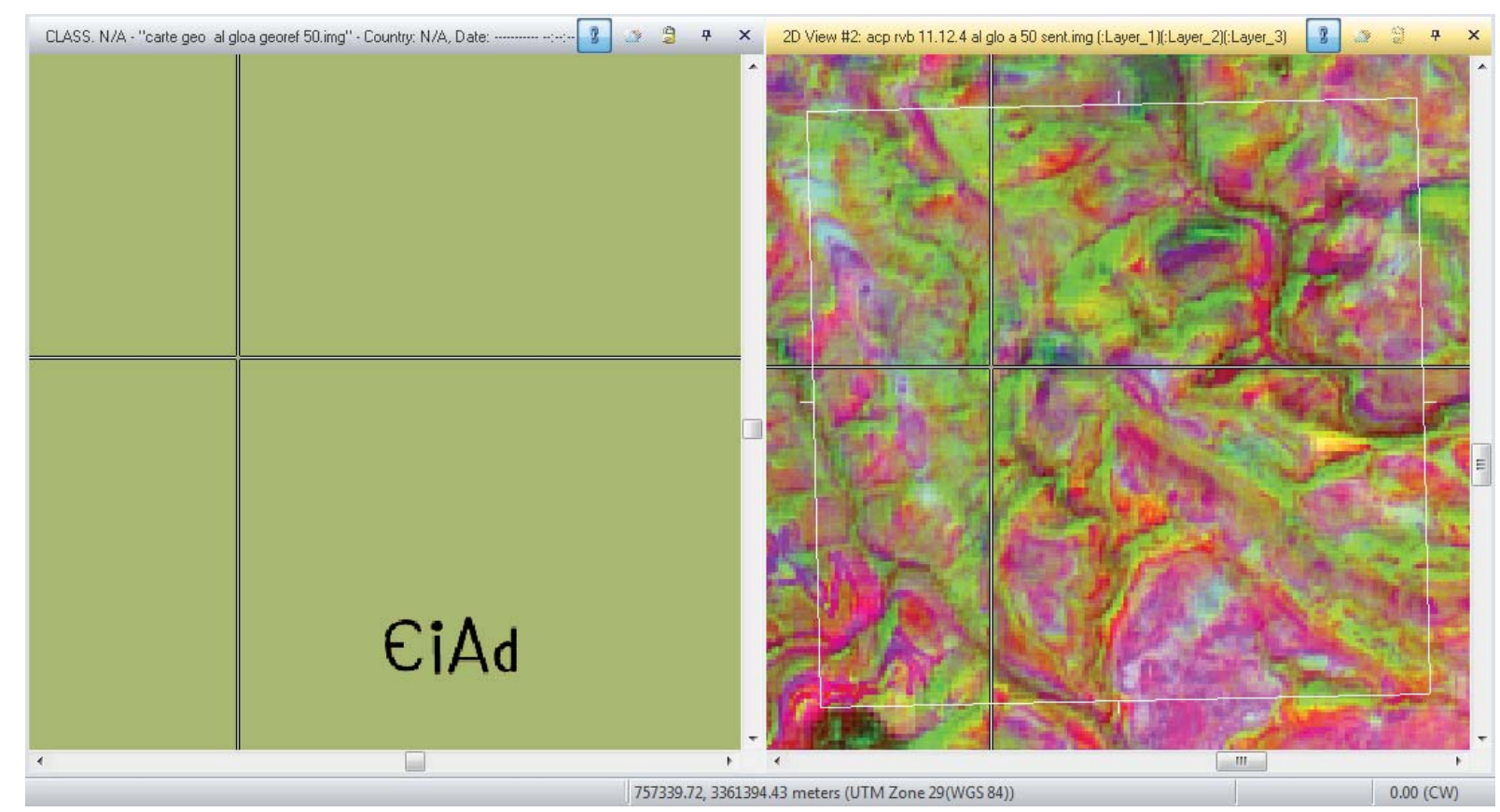

Fig. 13. Comparison between the PCA result and the geological map

Key: PCA, principal component analysis.

\subsection{Neo-channels}

Given the effectiveness of the PCA, RGB of the first major components (PC1 (11/12.11/2.11/8), PC1 (12.8.2), PC1 (11.12.2)) provide a good result (Figure 10a-c).

\subsection{Unsupervised classification "UC"}

The tests of "UC", according to the different algorithms ISODATA and K-Means, can achieve lithological cartographies (Figures 11 and 14). We have created several maps by changing the number of classes. Figure 14 presents a simple example of the results of 10 classes for the two algorithms. It also presents a similar result between the two cases (Table 7). 


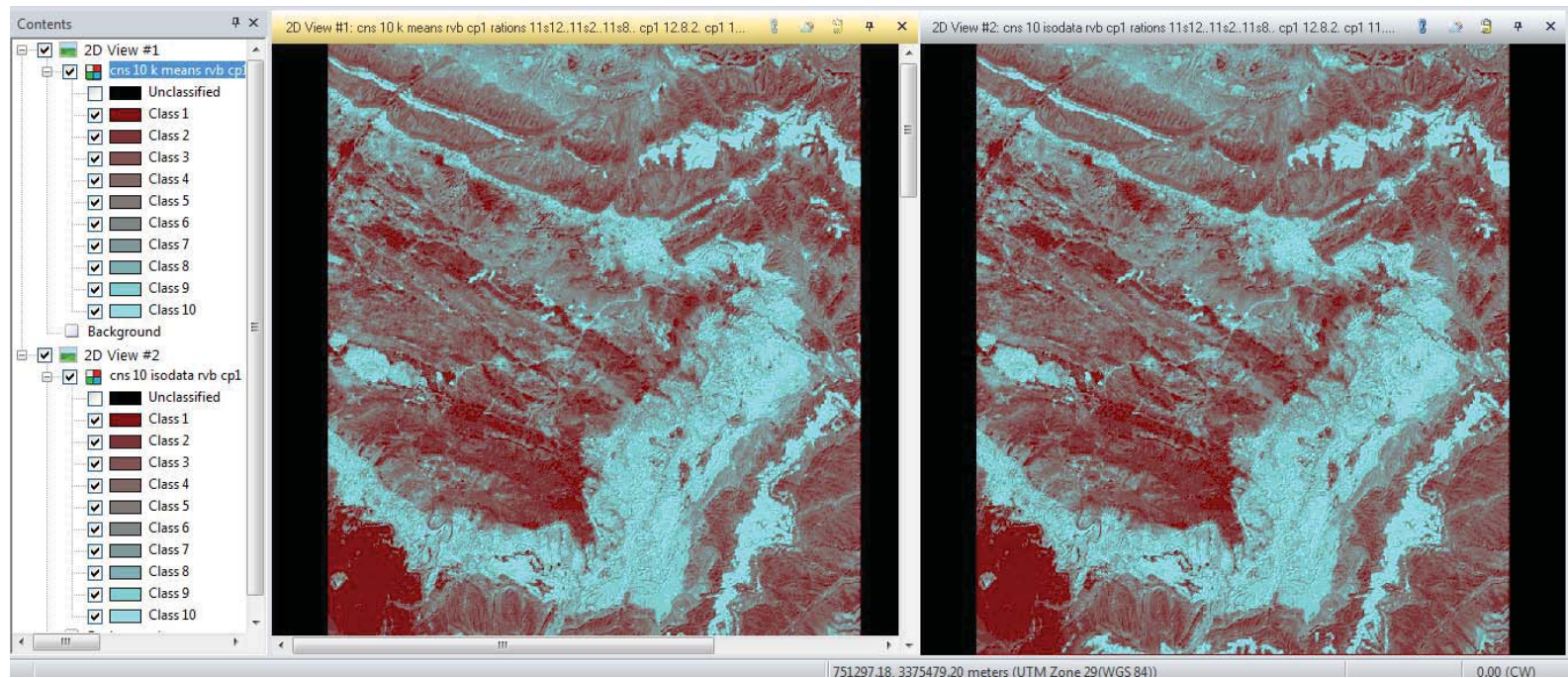

Fig. 14. Unsupervised classification of 10 classes of ISODATA and K-Means algorithms Key: ISODATA, Iterative Self-Organizing Data Analysis Technique.

Table 7. Geological formations of 10 classes of the classification

\begin{tabular}{|c|l|}
\hline Class & Geological formations \\
\hline 1 & $\begin{array}{l}\text { Basalts; alluvial fans associated with the middle terraces fluviatiles; homogeneous } \\
\text { basalts more or less doleritic; breccias and andesitic pyroclastic tuffs }\end{array}$ \\
\hline 2 & Sandstone oblique bed of megaripples and conglomerates \\
\hline 3 & Sedimentary layers (clay and sand) \\
\hline 4 & Sandstone; siltstones and basic siltstones \\
\hline 5 & Dark area (the shadow of the reliefs) \\
\hline 6 & $\begin{array}{l}\text { Silty argilites; sandstone with wrinkles; alternation of layers of stromatolitic } \\
\text { dolomite and heterolithic clay-silty facies with wrinkles of waves and desiccation } \\
\text { slits }\end{array}$ \\
\hline 7 & $\begin{array}{l}\text { Microbialite dolomites and clay interludes; sandstone with HCS (hummocky-cross } \\
\text { stratification) then tigillites and pelites }\end{array}$ \\
\hline 8 & Vegetation \\
\hline 9 & $\begin{array}{l}\text { Adoudou formation (microbialite dolomites and red clay-silty interludes; basal } \\
\text { sedimentary breccia) }\end{array}$ \\
\hline 10 & Igoudine formation (microbialite dolomites and clay interludes) \\
\hline
\end{tabular}

\subsection{Linear charts}

The first main component of RGB (PC1 (11/12.11/2.11/8), PC1 (12.8.2), PC1 (11.12.2)) has been processed to generate the lineaments (Figure 12). This case has given a satisfactory result (74\%), especially after the deletion of the lines, which corresponds to objects other than those of the faults, like the roads, the borders, the limits between the geological formations, the summits of the ridges, and the shadow of the objects.

\subsection{Validation of the results}

The results of 100 sites in the images and the geological map of the study area were verified randomly. This validation revealed that the validation rate with the field reality is of the order of: 
- $62 \%$ for the hydrothermal alteration zone;

- $81 \%$ for the lithological map, knowing that we tested only two images with 10 classes; so, this test does not take into account all the details of the geological map; and

- $74 \%$ for the structural map, if we take the geological map as a reference.

\section{CONCLUSIONS AND PROSPECTS}

This work aims to evaluate the image potential of MSI (13 spectral bands) for the mapping of mineral resources. The approach followed consists of several steps: 1) using satellite image processing methods of several satellites including Landsat 7, 8, and ASTER $30 \mathrm{~m}$ and the correspondence between their bands to create methods for Sentinel-2A images with a resolution of $10 \mathrm{~m}$; 2) visualizing the different ratios, normal RGBs, and other results from the PCA, we chose the images $(12.8 .2 ; 11 / 12.11 / 2.11 / 8$ and PC1,2,3(11.12.2)) that give good results in the field of geological discrimination; 3$)$ the new images ((PC1 (11/12.11/2.11/8), PC1 (12.8.2), PC1 (11.12.2)) are the subject of treatments through the PCA and unsupervised classification with ISODATA and K-Means algorithms to define lithology; and 4) other directional algorithms are used for structural mapping and the ratio 11/12 for hydrothermal alteration zones. It is possible to summarize the data presented in Figure 14 and Table 7, which are shown in Figure 15 that presents a geological map of 10 classes of the study area by the ISODATA algorithm. 


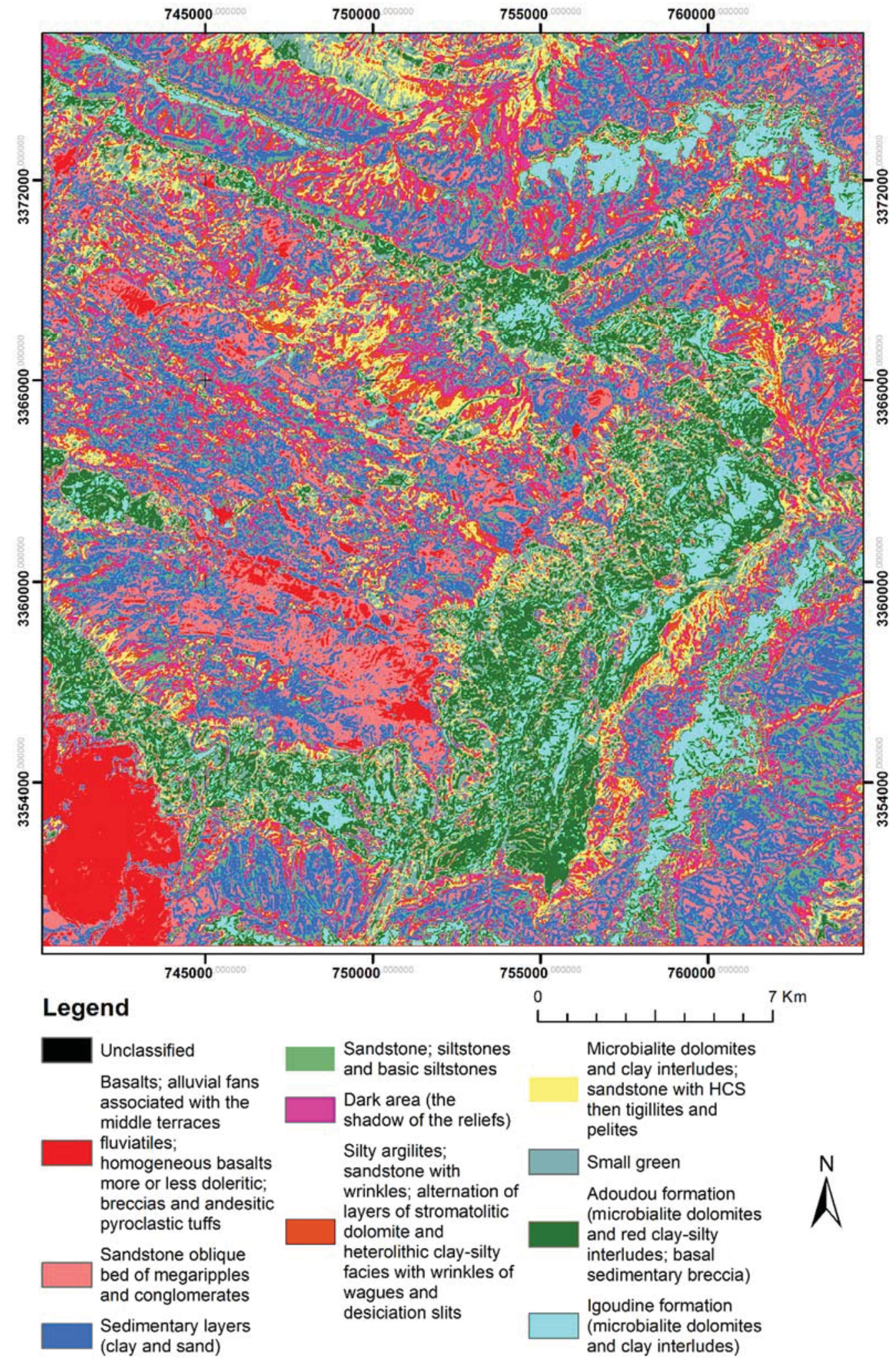

Fig. 15. Unsupervised classification with ISODATA algorithms (10 classes)

Key: ISODATA, Iterative Self-Organizing Data Analysis Technique.

These results allow us to identify the probable mining sites by interpretation of the lithological and structural data resulting from the image processing method, especially those related to the hydrothermal alteration zone. In our study area, Anti-Atlas, the overlaps 
between the Adoudounien formation and hydrothermal alteration have a favorable surface area for the genesis of copper deposits, especially with the existence of a structural anomaly such as faults, while the overlaps between the latter two and the Ordovician formation favor the creation of gold mineralization. Validation of results revealed that the validation rate with the field reality is of the order of $62 \%$ for the hydrothermal alteration zone, $81 \%$ for the lithological map, and $74 \%$ for the structural map.

These results remain of great use in mining prospecting to reduce both cost and time, especially in sites with difficult access, and to guide conventional methods of mining research. Future work will also focus on 1) hyperspectral imaging, 2) radar imagery, 3) optical radar fusion, and 4) multispectral and hyperspectral fusion to assess their potential, particularly when combined with other geophysical and geochemical data, for subsurface exploration.

\section{REFERENCES}

Achek, H., \& Aidouni, N.(2014) Essai de cartographie géologique par la télédétection optique de la région Hank (Sud-Ouest Algérien).

Adiri, Z., El-Harti, A., Jellouli, A., \& Maacha, L. (2016) Lithological mapping using Landsat 8 and ASTER multispectral data in the Bas Drâa inlier, Moroccan Anti Atlas. Journal of Applied Remote Sensing.

Al HAKIM, A., \& SULISTIJO, B. (2013) Integrated Exploration Method to Determine Cu Prospect In Seweden District, Blitar, East Java. Procedia Earth and Planetary Science, 64-69.

Amri, K., Mahdjoub, Y., \& Guergour, L. (2009) Apport des images Landsat 7 ETM+ pour la discrimination lithologique et l'étude structurale de la région d'Afara Héouine, Tahifet, Hoggar Central. Journées d'Animation Scientifique (JAS09) de l'AUF Alger.

Amri, K., Rabai, G., Benbakhti, I. M., \& Khennouche, M. N. (2017) Mapping geology in Djelfa District (Saharan Atlas, Algeria), using Landsat 7 ETM+ data: an alternative method to discern lithology and structural elements. Arab J Geosci.

Corumluoglu O., Vural A., \& Asri İ. (2015) Determination of Kula Basalts (Geosite) in Turkey using Remote Sensing Techniques". Journal of Arabian Geosciences. 8:1010510117. [HYPERLINK "http://spiedl.aip.org/jhtml/doi.jsp" doi: 10.1007/s12517-015-19144].

Escadafal, \& Peuget. (1987) Comparaison des données Landsat MSS et TM pour la cartographie des formations superficielles en zone aride (Tunisie méridionale)". in: Guyenne, T.D. (ed.); Calabresi, G. (ed.) - European coordinated effort for monitoring the earth's environment : a pilot project campaign on Landsat Thematic Mapper applications (1985-87): 301-307.

Gad S. \& Raef A. (2012) Factor analysis approach for composited ASTER band ratios and wavelet transform pixel-level image fusion: lithological mapping of the Neoproterozoic Wadi Kid area, Sinai, Egypt. International Journal of Remote Sensing, 33:5, 1488-1506. [HYPERLINK "http://spiedl.aip.org/jhtml/doi.jsp" doi: HYPERLINK "https://doi.org/10.1080/01431161.2011.577106" 10.1080/01431161.2011.577106].

GDAL (s.d.). Consulté le 12 15, 2017, sur GDAL - Geospatial Data Abstraction Library: http://www.gdal.org/frmt_sentinel2.html 
Imessaoudene, M. (2012) Utilisation de la télédétection pour la cartographie géologique du Massif des Eglab et de sa bordure sédimentaire (Sud-Ouest algérien). MEMOIRE DE FIN D'ETUDE, UNIVERSITE FERHAT ABBAS - SETIF, INSTITUT D'ARCHITECTURE \&DES SCIENCES.

Mike, A. (2005, 08 02). Les données Aster.

Mwaniki, M. W., Moeller, M. S., \& Schellmann, G. (2015) A comparison of Landsat 8 (OLI) and Landsat $7(\mathrm{ETM}+)$ in mapping geology and visualising lineaments: A case study of central region Kenya. The International Archives of the Photogrammetry, Remote Sensing and Spatial Information Sciences, XL-7/W3.

Nair A. \& Mathew G. (2012) Lithological discrimination of the Phenaimata felsic-mafic complex, Gujarat, India, using the Advanced Spaceborne Thermal Emission and Reflection Radiometer (ASTER). International Journal of Remote Sensing, 33:1, 198219. [doi: HYPERLINK "https://doi.org/10.1080/01431161.2011.591441" 10.1080/01431161.2011.591441 ].

Öztan N. \& Süzen M. (2011) Mapping evaporate minerals by ASTER. International Journal of Remote Sensing, 32:6, 1651-1673. [HYPERLINK "http://spiedl.aip.org/jhtml/doi.jsp" doi: HYPERLINK "https://doi.org/10.1080/01431160903586799" 10.1080/01431160903586799].

Ouattara, G., Koffi, G., \& Yao, A. (2012)Contribution des images satellitales Landsat 7 ETM+ à la cartographie lithostructurale du Centre-Est de la Cote d'Ivoire (Afrique de l'Ouest). International Journal of Innovation and Applied Studies, 61-75.

Pour, A., \& Hashim, M. (2014) Hydrothermal alteration mapping using Landsat-8 data, Sar Cheshmeh copper mining district, SE Iran. Journal of Taibah University for Science.

Qaid, A. M., \& Basavarajappa, H. (2008) Application of Optimum Index Factor Technique to Landsat-7 Data for Geological Mapping of North East of Hajjah, Yemen. AmericanEurasian Journal of Scientific Research, 84-91.

SHADDAD, I. A. (2005) APPLICATION OF REMOTE SENSING TECHNIQUES FOR REGIONAL GEOLOGICAL SURVEY IN SOME SELECTED AREAS, SUDAN. Workshop International Télédétection et Systèmes d'Information Géographique "Information Spatiale et Développement Durable", 35-36.

Shahriari H., Honarmand M. \& Ranjbar H. (2015) Comparison of multi-temporal ASTER images for hydrothermal alteration mapping using a fractal-aided SAM method. International Journal of Remote Sensing, 36:5, 1271-1289. [HYPERLINK "http://spiedl.aip.org/jhtml/doi.jsp" doi: HYPERLINK "https://doi.org/10.1080/01431161.2015.1011352" 10.1080/01431161.2015.1011352].

Soulaimani A., Admou H., Fekkak A., Égal E., Roger J., Youbi N., Razin Ph., Blein O., Baudin T. (2013a) Carte géol. Maroc (1/50 000), feuille Al Glo'a - Notes et Mémoires Serv. Géol. Maroc, N532, MEM/BRGM. Notice explicative par A. Soulaimani, E. Egal, Ph. Razin, N. Youbi, H. Admou, O. Blein, L. Barbanson, D. Gasquet, M. Bouabdelli, Anzar Conseil. 
Soulaimani A., Egal E., Razin Ph., Youbi N., Admou H., Blein O., Barbanson L., Gasquet D., Bouabdelli M., Anzar Conseil (2013b) Notice explicative carte géol. Maroc (1/50 000), feuille Al Glo’a, Notes et Mémoires Serv. Géol. Maroc, N`532 bis, MEM/BRGM. Carte géologique par Soulaimani A., Admou H., Fekkak A., Égal E., Roger J., Youbi N., Razin Ph., Blein O., Baudin T., (2013) (HYPERLINK "https://www.researchgate.net/profile/Soulaimani_Abderrahmane/publication/278776652_ Notice_explicative_de_la_Carte_geologiques_du_Maroc_150_000_feuille_Al_Gloa/links/ 55f800b508ae07629dce95d7/Notice-explicative-de-la-Carte-geologiques-du-Maroc-1-50000-feuille-Al-Gloa.pdf" https://www.researchgate.net/profile/Soulaimani_Abderrahmane/publication/278776652_ Notice_explicative_de_la_Carte_geologiques_du_Maroc_150_000_feuille_Al_Gloa/links/ 55f800b508ae07629dce95d7/Notice-explicative-de-la-Carte-geologiques-du-Maroc-1-50000-feuille-Al-Gloa.pdf ).

USGS Landsat Program. (s.d.). Consulté le 12 15, 2017, sur USGS Landsat Program: https://twitter.com/usgslandsat/status/837696716417687553

Vural, A., Corumluoglu, O., \& Asri, I. (2016) Exploring Gördes Zeolite Sites by Feature Oriented Principle Component Analysis of LANDSAT Images. Caspian Journal of Environmental Sciences, 14(4), 285-298.

Vural A., Corumluoglu O., \& Asri I. (2017) Remote Sensing Technique for Capturing and Exploration of Mineral Deposit Sites in Gümüşhane Metallogenic Province, Ne Turkey. Journal of Geological Society of India. 90 (5):625-633. [HYPERLINK "http://spiedl.aip.org/jhtml/doi.jsp" doi: 10.1007/s1259].

Wang W., Zhou W., Yang R., Yuan T. (2015) Development and application of the alteration mineral information extraction system based on ASTER data. Proc. SPIE 9675, AOPC 2015: Image Processing and Analysis, 96750P.

Received: 2019-07-29,

Reviewed: 2019-09-30, and 2019-11-07, by J.R. Olędzki, Accepted: 2019-12-04. 